\title{
A novel function of poly(ADP-ribose) polymerase-1 in modulation of autophagy and necrosis under oxidative
} stress - Retracted -

\author{
Q Huang ${ }^{1}$, Y-T Wu ${ }^{1}$, H-L Tan ${ }^{1}$, C-N Ong ${ }^{1}$ and H-M Shen ${ }^{*, 1}$
}

Under oxidative stress, poly(ADP-ribose) polymerase-1 (PARP-1) is activated and contributes to necrotic cell death through ATP depletion. On the other hand, oxidative stress is known to stimulate autophagy, and autophagy may act as either a cell death or cell survival mechanism. This study aims to explore the regulatory role of PARP-1 in oxidative stress-mediated autophagy and necrotic cell death. Here, we first show that hydrogen peroxide $\left(\mathrm{H}_{2} \mathrm{O}_{2}\right)$ induces necrotic cell death in $\mathrm{Bax}-/-\mathrm{Bak}-/-$ mouse embryonic fibroblasts through a mechanism involving PARP-1 activation and ATP depletion. Next, we provide evidence that autophagy is activated in cells exposed to $\mathrm{H}_{2} \mathrm{O}_{2}$. More importantly, we identify a novel autophagy signaling mechanism linking PARP-1 to the serine/threonine protein kinase LKB1-AMP-activated protein kinase (AMPK)-mammalian target of rapamycin (mTOR) pathway, leading to stimulation of autophagy. Finally, we demonstrate that autophagy plays a cytoprotective role in $\mathrm{H}_{2} \mathrm{O}_{2}$-induced necrotic cell death, as suppression of autophagy by knockdown of autophagy-related gene ATG5 or ATG7 greatly sensitizes $\mathrm{H}_{2} \mathrm{O}_{2}$-induced cell death. Taken together, these findings demonstrate a novel function of PARP-1: promotion of autophagy through the LKB1-AMPK-mTOR pathway to enhance cell survival in cells under oxidative stress.

Cell Death and Differentiation (2009) 16, 264-277; doi:10.1038/cdd.2008.151; published online 31 October 2008

Oxidative stress refers to a status of cellular redox imbalance caused by an overabundance of reactive oxygen species (ROS) and/or a decline in antioxidant ability. ${ }^{1}$ Oxidative stress and ROS are known to be implicated in a number of physiological and pathological processes, leading to various biological consequences including cell death (either apoptotic or non-apoptotic/necrotic cell death). ${ }^{2}$ In comparison with ROS-mediated apoptosis, the molecular mechanisms underlying ROS-mediated non-apoptotic/necrotic cell death have not been well elucidated. Poly(ADP-ribose) polymerase-1 (PARP-1) is the founding member of the PARP family, a group of nuclear enzymes that play a critical role in DNA damage repair through poly(ADP-ribosyl)ation. ${ }^{3}$ It is known that poly(ADP-ribosyl)ation is an energetically expensive process, causing rapid depletion of cellular $\beta$-nicotinamide adenine dinucleotide $(\mathrm{NAD}+)$, failure in ATP production, and eventually necrotic cell death. ${ }^{3,4}$ In cells under oxidative stress, PARP-1 activation has been well established as a key mechanism in necrotic cell death. ${ }^{4-6}$

Autophagy is a highly conserved self-eating process, in which intracellular membrane structures engulfed a portion of cytoplasm and organelles for lysosomal degradation. ${ }^{7}$ Autophagy has been reported to have its fundamental roles in cellular homeostasis, and exert as either a survival-prone or cell death-prone mechanism in different physiological and pathological conditions. ${ }^{8}$ Under many scenarios, such as nutrient depletion and metabolic stress, autophagy is induced to produce metabolic substrates that meet the bioenergetic needs of cells and to prevent cell death. ${ }^{9,10}$ On the other hand, autophagy has been suggested to be a cell death mechanism, leading to autophagic cell death or type II programmed cell death. ${ }^{11}$ For instance, some DNA damage agents, such as etoposide (ETO), induced non-apoptotic cell death dependent on autophagy genes in cells lacking Bax and Bak expression. ${ }^{12}$

At present, there is accumulating evidence suggesting the involvement of autophagy in the physiological and pathological responses to oxidative stress. ${ }^{13}$ For instance, repression of autophagic pathways was observed to be concurrent with the accumulation of oxidized proteins in age-related disorders, such as Alzheimer's disease. ${ }^{14}$ Currently there are two important issues remain unresolved. First, the signaling pathway linking oxidative stress and autophagy is yet to be fully elucidated. An earlier study provided evidence that ROS contributes to starvation-induced autophagy through direct oxidation of autophagy-related gene (ATG) $4 .{ }^{15}$ It remains to be determined whether and how ROS affect the autophagy regulatory mechanism upstream of ATGs. Second, the role of autophagy in cellular response to oxidative stress is found to be controversial. ROS has been reported to induce autophagy, which contributes to caspase-independent cell death in a variety of cell types including macrophage, HEK293, U87 and HeLa cells. ${ }^{16,17}$ On the other hand, a number of other studies demonstrated a protective role of autophagy against

\footnotetext{
${ }^{1}$ Department of Community, Occupational \& Family Medicine, Yong Loo Lin School of Medicine, National University of Singapore, Singapore 117597, Singapore *Corresponding author: H-M Shen, Department of Community, Occupational \& Family Medicine, Yong Loo Lin School of Medicine, National University of Singapore, Singapore 117597, Singapore. Tel: + 656516 4998; Fax: + 656779 1489; E-mail: cofshm@nus.edu.sg

Keywords: autophagy; AMPK; mTOR; ROS; PARP-1; necrosis

Abbreviations: 3AB, 3-amino benzamide; AMPK, AMP-activated protein kinase; ATG, autophagy-related gene; CHX, cycloheximide; CQ, chloroquine; DMEM, Dulbecco's modified Eagle's medium; ETO, etoposide; MEFs, mouse embryonic fibroblasts; MP, methylpyruvate; mTOR, mammalian target of rapamycin; PARP-1, Poly(ADP-Ribose) Polymerase-1; PI, propidium iodide; ROS, reactive oxygen species

Received 28.4.08; revised 01.9.08; accepted 16.9.08; Edited by E Baehrecke; published online 31.10.08
} 
ROS-mediated necrosis. Recent work in our laboratory has demonstrated that autophagy serves as a cell survival mechanism in zVAD-induced necrotic cell death, ${ }^{18}$ a process involving ROS and oxidative stress. ${ }^{19}$ Moreover, ROS are found to promote survival-prone autophagy under several stress conditions, including starvation and ischemia/reperfusion. ${ }^{15,20}$ Therefore, in this study, we aim to further explore the signaling pathway linking oxidative stress and autophagy and the functional role of autophagy in ROS-induced necrotic cell death in Bax/Bak double-knockout (Bax-/- Bak-/-) mouse embryonic fibroblasts (MEFs), a well-established model to study necrotic cell death. ${ }^{21}$ Here, we identify a novel function of PARP-1 in regulation of autophagy through activation of serine/threonine protein kinase LKB1 and AMP-activated protein kinase (AMPK) and subsequent suppression of mammalian target of rapamycin (mTOR), and such autophagy serves as a cell survival mechanism to counteract ROSmediated necrosis. Understanding the novel function of PARP-1 in regulation of autophagy helps to dissect the complex relationship among oxidative stress, autophagy and cell death.

\section{Results}

$\mathrm{H}_{2} \mathrm{O}_{2}$ induces caspase-independent necrotic cell death. In this study, we first examined hydrogen peroxide
$\left(\mathrm{H}_{2} \mathrm{O}_{2}\right)$-induced cell death in Bax-/- Bak-/- MEFs, a cell line widely used for studying necrosis. ${ }^{21} \mathrm{H}_{2} \mathrm{O}_{2}$ induced significant cell death in a concentration- and timedependent manner, quantified by the propidium iodide (PI) exclusion test coupled with flow cytometry (Figure 1a). Furthermore, there was no caspase 3 or PARP cleavage in cells treated with $\mathrm{H}_{2} \mathrm{O}_{2}$ (Figure $1 \mathrm{~b}$ ). zVAD, a pan-caspase inhibitor, failed to block $\mathrm{H}_{2} \mathrm{O}_{2}$-indcued cell death (Figure 1c), while completely blocked TNF $\alpha$-induced PARP cleavage (Figure 1b). These findings indicate that $\mathrm{H}_{2} \mathrm{O}_{2}$ induces caspase-independent necrotic cell death $\mathrm{Bax}-/ \mathrm{-Bak}-/-$ MEFs. Similar results were also observed using wild-type MEFs (wt MEFs) (Supplementary Figure 1a and b), which are consistent with our previous report. ${ }^{22}$

PARP-1 activation contributes to $\mathrm{H}_{2} \mathrm{O}_{2}$-induced cell death. Poly(ADP-ribose) polymerase-1 is readily activated in response to DNA damage and well associated with necrotic cell death. ${ }^{3}$ As shown in Figure $2 \mathrm{a}$, a strong formation of poly (ADP-ribose) (PAR) polymer, a direct result of PARP-1 activation, was detected as early as $10 \mathrm{~min}$ after $\mathrm{H}_{2} \mathrm{O}_{2}$ exposure. Intracellular ATP level was also decreased dramatically after $\mathrm{H}_{2} \mathrm{O}_{2}$ treatment (Figure $2 \mathrm{~b}$ ). To verify whether PARP-1 activation contributes to the cell death induced by $\mathrm{H}_{2} \mathrm{O}_{2}$, cells were treated with $\mathrm{H}_{2} \mathrm{O}_{2}$ in the presence or absence of 3-amino benzamide (3AB), a specific

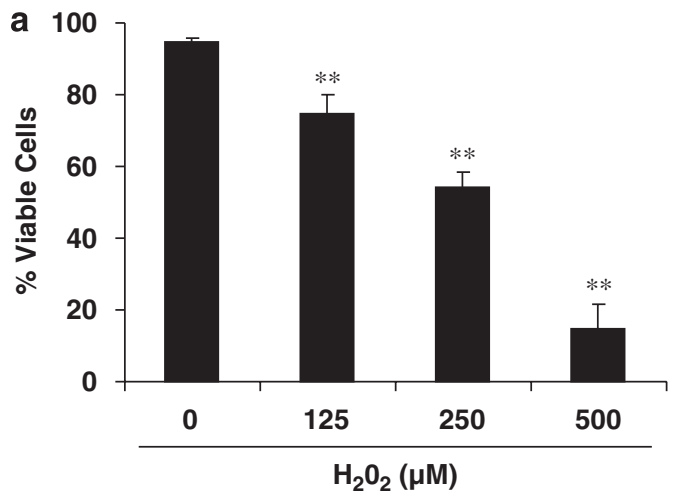

b $\begin{array}{lllll}\text { CTRL } & \mathrm{H}_{2} \mathrm{O}_{2} & \text { zVAD } & \begin{array}{l}\mathrm{CHX}+ \\ \mathrm{TNF} \alpha\end{array} & \text { ZVAX+TNF } \alpha\end{array}$
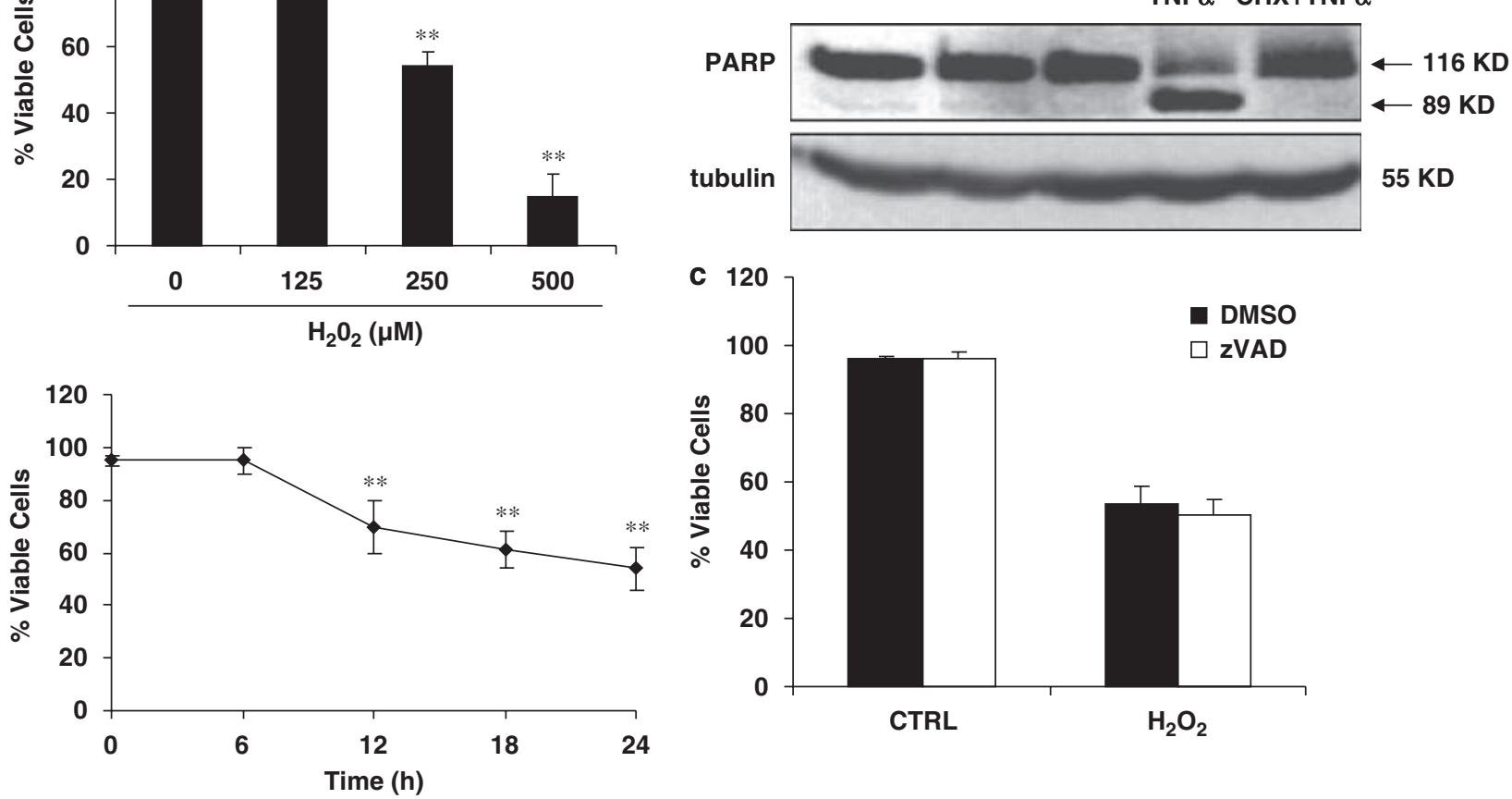

Figure 1 Hydrogen peroxide $\left(\mathrm{H}_{2} \mathrm{O}_{2}\right)$ induces caspase-independent necrotic cell death in $\mathrm{Bax}-/-\mathrm{Bak}-/-\mathrm{MEFs}$. (a) Concentration- and time-dependent cell death induced by $\mathrm{H}_{2} \mathrm{O}_{2}$ in $\mathrm{Bax}-/-\mathrm{Bak}-/-\mathrm{MEFs}$. Upper panel: cells were incubated with designated concentration of $\mathrm{H}_{2} \mathrm{O}_{2}$ for $24 \mathrm{~h}$; lower panel: cells were treated with $\mathrm{H}_{2} \mathrm{O}_{2}$ $(250 \mu \mathrm{M})$ for designated periods of time. (b) PARP cleavage detected by western blot. Bax-/- Bak-/- MEFs were treated with $\mathrm{H}_{2} \mathrm{O}_{2}(250 \mu \mathrm{M} \times$ for $12 \mathrm{~h})$ or TNF- $\alpha(25 \mathrm{ng} / \mathrm{ml})$ plus $\mathrm{CHX}(10 \mu \mathrm{g} / \mathrm{ml})$ for $12 \mathrm{~h}$ in the presence or absence of $\mathrm{ZVAD}(50 \mu \mathrm{M})$. (c) $\mathrm{zVAD}$ was unable to block $\mathrm{H}_{2} \mathrm{O}_{2}$-induced cell death. Cells were treated with $\mathrm{H}_{2} \mathrm{O}_{2}(250 \mu \mathrm{M} \times$ for $24 \mathrm{~h}$ ) with or without $\mathrm{ZVAD}(50 \mu \mathrm{M})$. In (a and $\mathbf{c})$, cell survival was determined using the Pl exclusion test coupled with flow cytometry. Data were presented as means \pm S.D. of three independent experiments $\left({ }^{\star \star} P<0.01\right.$ comparing with the untreated control group, $t$-test) 

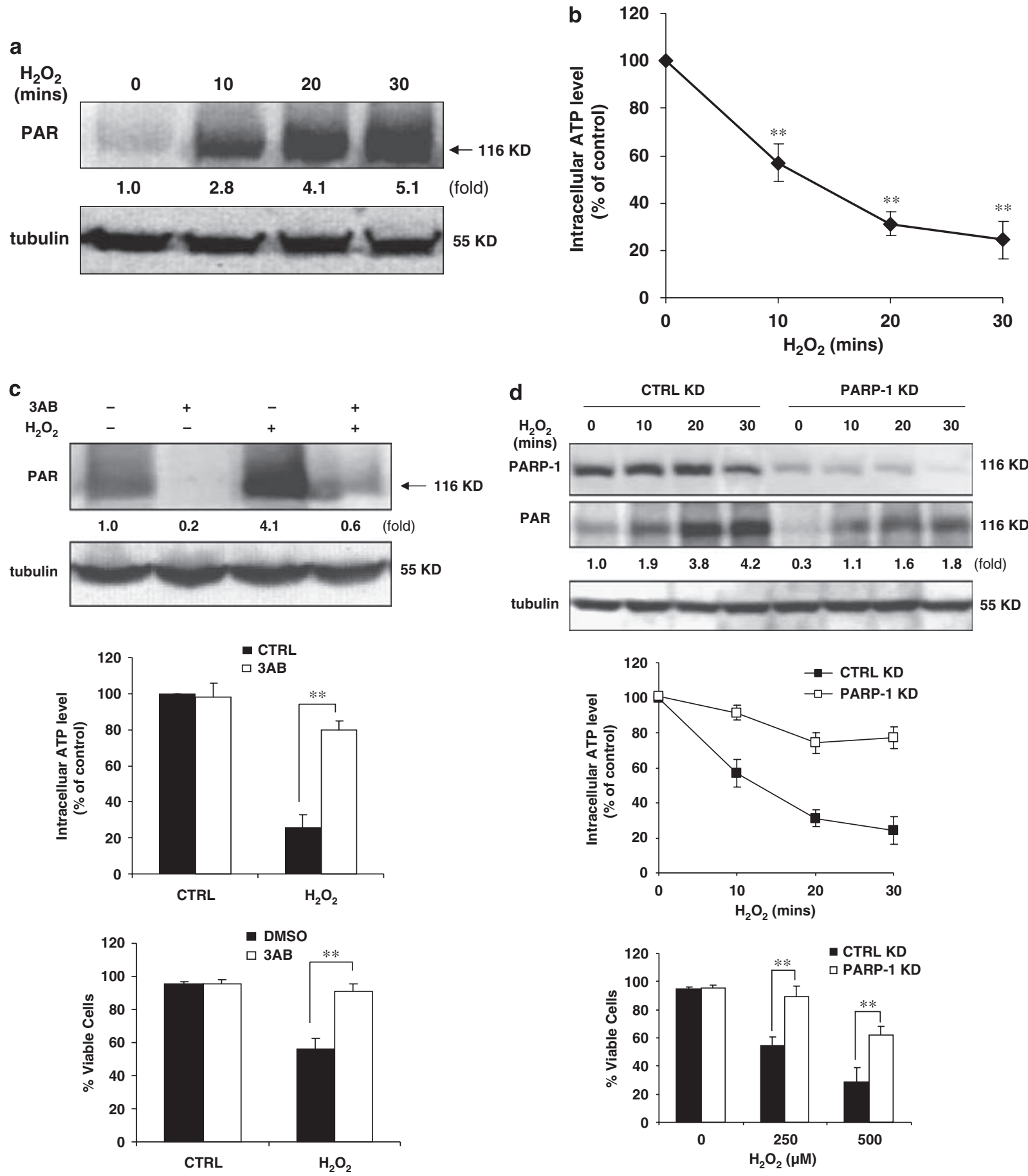

Figure 2 Poly(ADP-ribose) polymerase-1 (PARP-1) activation is associated with $\mathrm{H}_{2} \mathrm{O}_{2}$-induced cell death. (a) $\mathrm{H}_{2} \mathrm{O}_{2}$-induced PARP-1 activation. Bax-/- Bak-/- MEFs were treated with $\mathrm{H}_{2} \mathrm{O}_{2}(250 \mu \mathrm{M})$ up to 30 min. The formation of PAR polymer was detected by western blot. (b) $\mathrm{H}_{2} \mathrm{O}_{2}$-induced intracellular ATP depletion. Cells were treated as in (a). The cellular ATP level was measured as described in Materials and Methods. The ATP level was presented as percentage to the untreated control group. Data were shown as means \pm S.D. of three independent experiments $\left({ }^{\star *} P<0.01\right.$ comparing to the untreated group, $t$-test) (c) Effect of $3 A B$ on $\mathrm{H}_{2} \mathrm{O}_{2}$-induced PARP activation, intracellular ATP depletion and cell death. Cells were treated with $\mathrm{H}_{2} \mathrm{O}_{2}(250 \mu \mathrm{M} \times$ for $0.5 \mathrm{~h})$ with or without $1 \mathrm{~h}$ pretreatment of $3 \mathrm{AB}(10 \mathrm{mM})$. Cells were collected and subjected to western blot for analysis (upper panel) and cellular ATP measurement (middle panel). Cell survival was measured after $24 \mathrm{~h}$ of $\mathrm{H}_{2} \mathrm{O}_{2}$ treatment using the PI exclusion test coupled with flow cytometry (lower panel) ${ }^{* *} P<0.01$, $t$-test). (d) Effect of PARP-1 knockdown on $\mathrm{H}_{2} \mathrm{O}_{2}$-induced PARP activation, intracellular ATP depletion and cell death. Knockdown of PARP-1 expression by siRNAs was performed as described in Materials and Methods. After $72 \mathrm{~h}$ of siRNA transfection, cells were treated with $\mathrm{H}_{2} \mathrm{O}_{2}(250 \mu \mathrm{M})$ for designated periods of time. Cells were then collected and subjected to western blot for detection (upper panel) and cellular ATP measurement (middle panel). Cell survival was measured after $24 \mathrm{~h}$ of $\mathrm{H}_{2} \mathrm{O}_{2}$ treatment by PI exclusion test (lower panel) $\left({ }^{* \star} P<0.01, t\right.$-test). In $(\mathbf{a}, \mathbf{c}$ and $\mathbf{d})$, the level of PAR was quantified and the means (fold of changes over the control group) of three independent experiments were presented 
(Figure 2c). Similar results were found when we used a genetic approach by transient PARP-1 knockdown (Figure 2d). Meanwhile, to further confirm the role of ATP
PARP-1 inhibitor. Pretreatment with $3 A B$ significantly depletion and cell death in Bax-/- Bak-/- MEFs

\section{a}

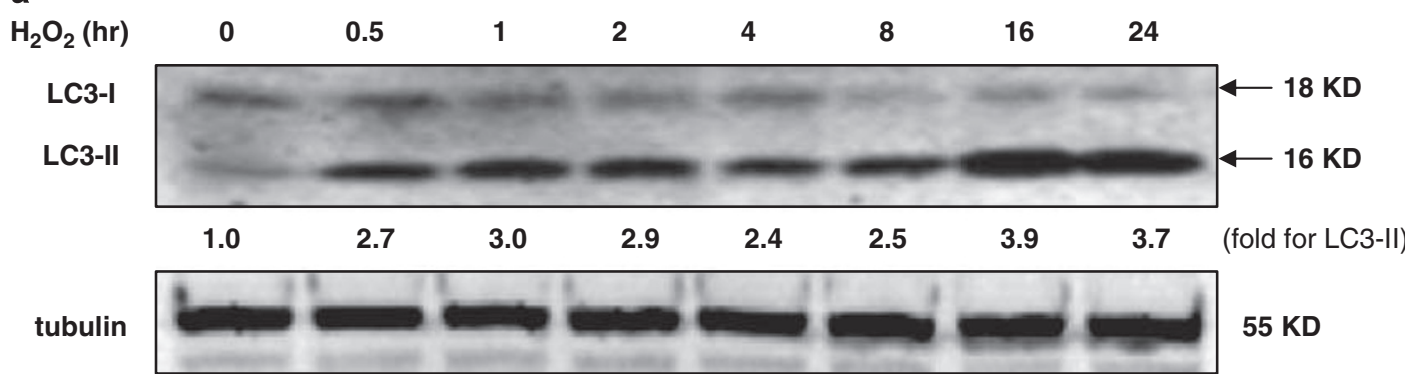

b

GFP

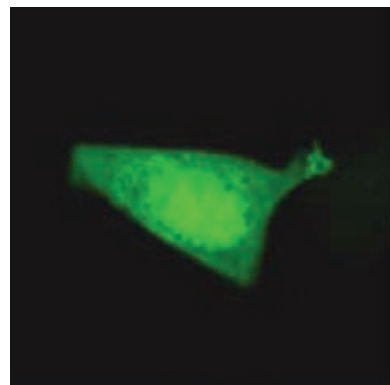

$\mathrm{H}_{2} \mathrm{O}_{2}$

30 mins

0 mins

$$
60 \text { mins }
$$
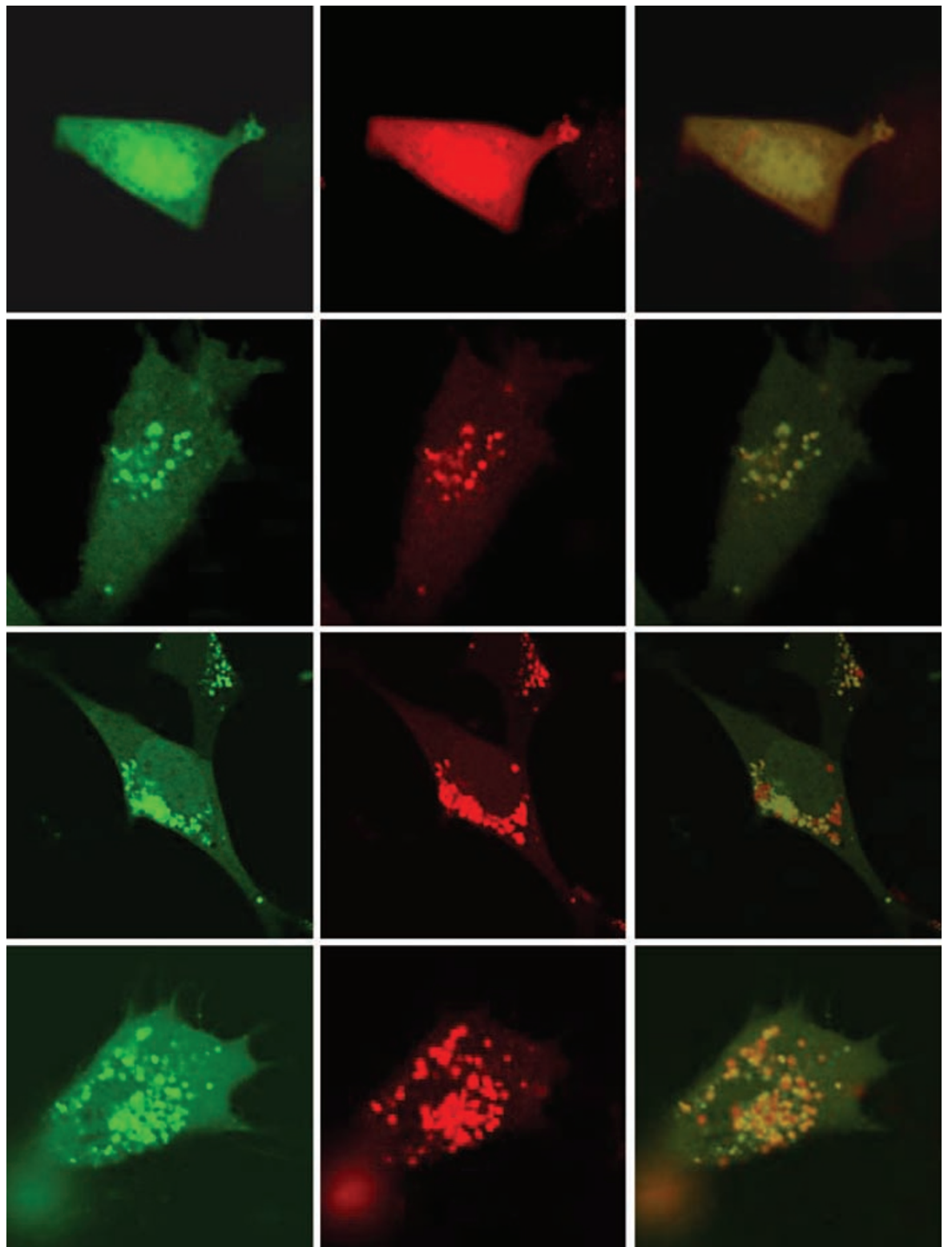

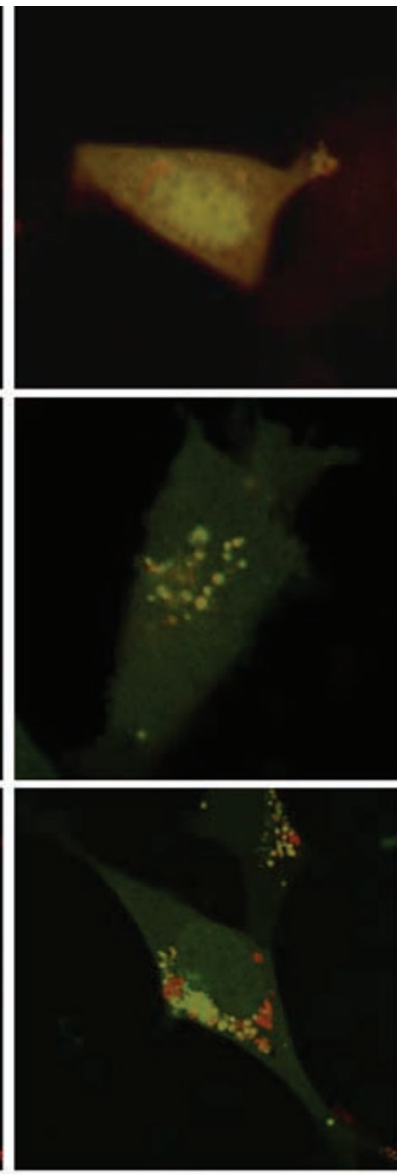

Merged

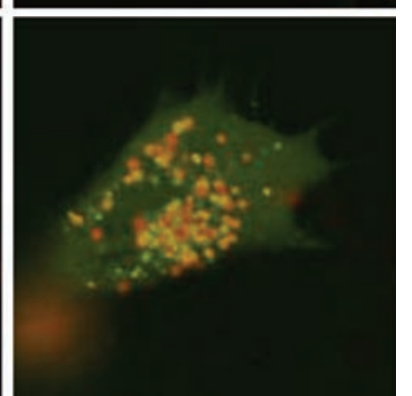

Figure 3 continued 

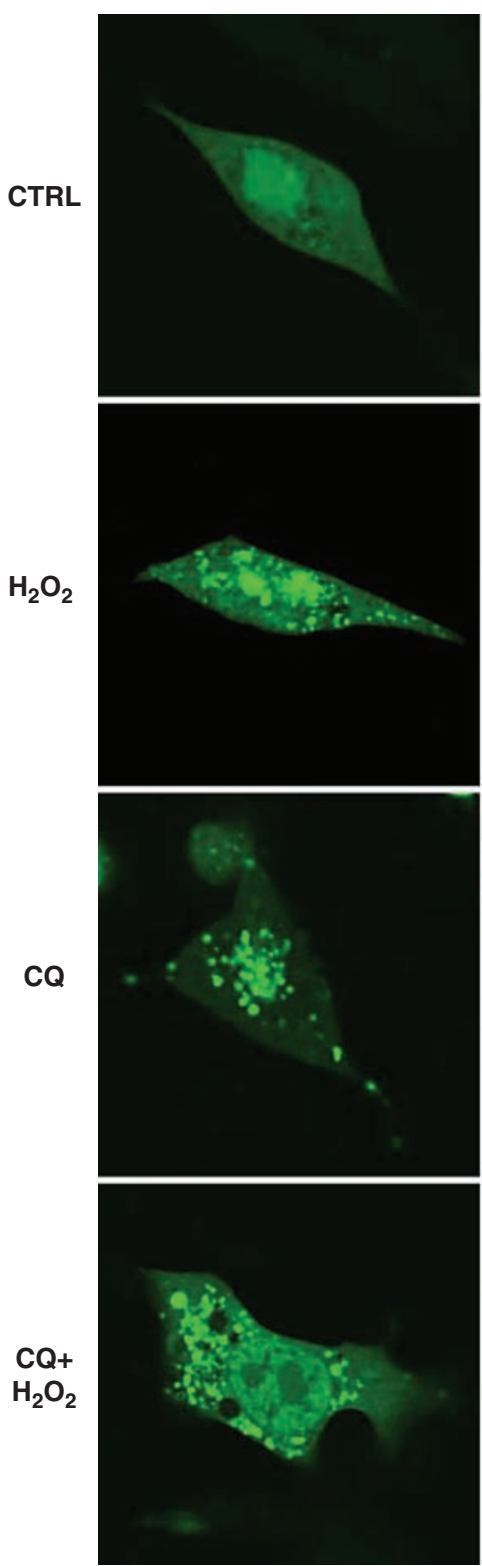

mRFP
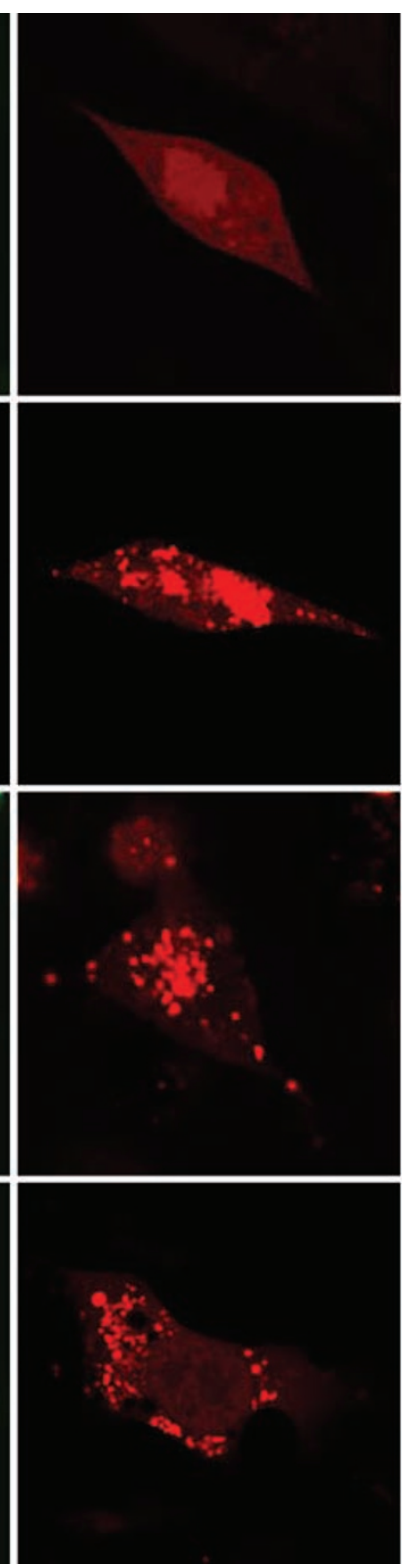

Merged
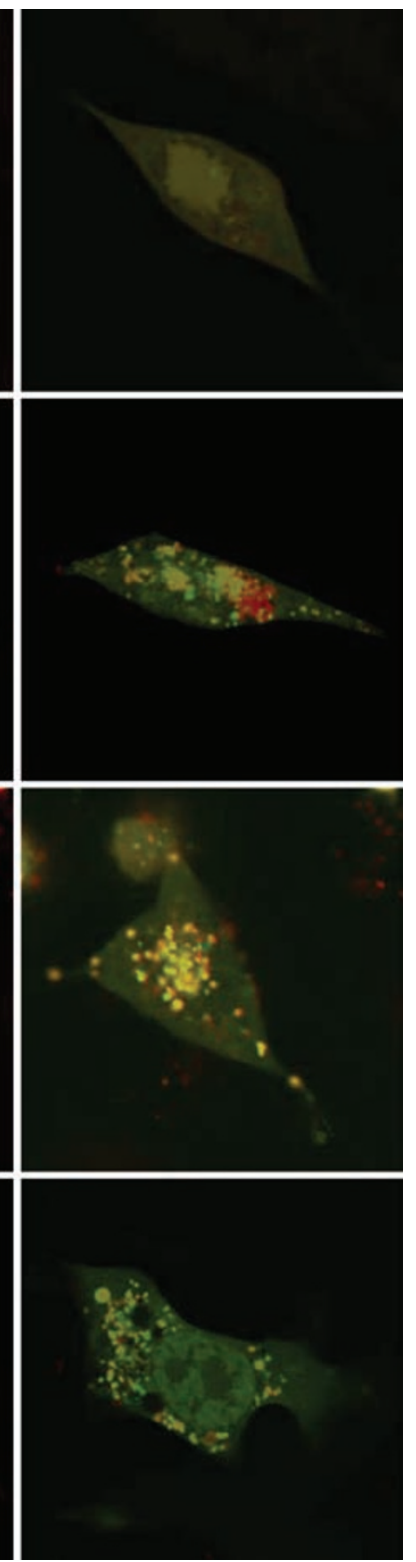

Figure 3 Hydrogen peroxide $\left(\mathrm{H}_{2} \mathrm{O}_{2}\right)$ induces functional autophagy. (a) Conversion of LC3-I to LC3-II induced by $\mathrm{H}_{2} \mathrm{O}_{2}$ treatment. Bax-/- Bak-/- MEFs were treated with $\mathrm{H}_{2} \mathrm{O}_{2}(250 \mu \mathrm{M})$ for various time and subjected to western blot for detection. The level of LC3-II was quantified and the means (fold of changes over the control group) of three independent experiments were presented. (b) Autophagosome maturation detected by selective reduction of the GFP fluorescence in cells expressing the GFP-mRFPLC3 fusion protein. Bax-/- Bak-/- MEFs were transiently transfected with the GFP-mRFP-LC3 plasmid for $24 \mathrm{~h}$ and then incubated with $\mathrm{H}_{2} \mathrm{O}_{2}(250 \mu \mathrm{M})$ up to $2 \mathrm{~h}$. The cells were examined by confocal microscopy, and representative cells were selected and photographed at designated time points. (c) Chloroquine (CQ) blocked autophagosome maturation in cells treated with $\mathrm{H}_{2} \mathrm{O}_{2}$. Cells were first transfected with the GFP-mRFP-LC3 plasmid as described in (b), followed by pretreatment with CQ (40 $\mu \mathrm{M} \times$ for $1 \mathrm{~h}$ ) and then $\mathrm{H}_{2} \mathrm{O}_{2}(250 \mu \mathrm{M})$ for $2 \mathrm{~h}$. The cells were examined and photographed

depletion in $\mathrm{H}_{2} \mathrm{O}_{2}$-induced cell death, we pretreated the cells with methylpyruvate (MP), a cell-permeable pyruvate, which can be oxidized to produce NADH that fuels ATP production. ${ }^{23}$ MP pretreatment restored ATP level in $\mathrm{H}_{2} \mathrm{O}_{2}$ treated cells (Supplementary Figure 2a) and significantly suppressed $\mathrm{H}_{2} \mathrm{O}_{2}$-induced cell death (Supplementary Figure 2b). Collectively, these results clearly suggest that PARP-1 activation and subsequent ATP depletion contribute to $\mathrm{H}_{2} \mathrm{O}_{2}$ induced necrotic cell death.
$\mathrm{H}_{2} \mathrm{O}_{2}$ induces autophagy. Autophagy has been implicated in ROS-mediated biological responses. ${ }^{13}$ When Bax-/Bak-/- cells were treated with $\mathrm{H}_{2} \mathrm{O}_{2}$, there was significant LC3-I to LC3-II conversion from 30 min onwards (Figure 3a). Similar LC3-I to LC3-II conversion was observed in wt MEFs treated with $\mathrm{H}_{2} \mathrm{O}_{2}$ (Supplementary Figure 1c). Furthermore, to confirm whether $\mathrm{H}_{2} \mathrm{O}_{2}$ induces functional autophagy or it damages lysosome function and blocks the turnover of autophagosome, we utilized the GFP-mRFP-LC3 construct 
to dissect the autophagosome maturation process. ${ }^{18,24}$ As shown in Figure $3 \mathrm{~b}$, at the later stage of $\mathrm{H}_{2} \mathrm{O}_{2}$ treatment ( 1 and $2 \mathrm{~h}$ ) there was significant reduction of punctuated GFP fluorescence in some autophagosomes, while the mRFP signal was largely unaffected, suggesting the completion of autophagosome maturation and lysosomal degradation. Moreover, as shown in Figure $3 \mathrm{c}$, the reduction of the GFP fluorescence was blocked when cells were pretreated with chloroquine (CQ), a well-known lysosomal enzyme inhibitor. Taken together with the data in Figure $3 a$, it is believed that $\mathrm{H}_{2} \mathrm{O}_{2}$ induces a functional autophagy in Bax-/- Bak-/MEFs.

PARP-1 activation contributes to $\mathrm{H}_{2} \mathrm{O}_{2}$-induced autophagy. Following the same approaches for PARP-1 inhibition, it is interesting to note that $3 A B$, a specific inhibitor of PARP-1, significantly blocked $\mathrm{H}_{2} \mathrm{O}_{2}$-induced LC3-I to LC3II conversion (Figure 4a). Similar inhibitory effect on LC3-I to LC3-II conversion was also found with PARP-1 knockdown (Figure 4b). Moreover, 3AB pretreatment almost completely blocked $\mathrm{H}_{2} \mathrm{O}_{2}$-induced autophagosome formation indicated by the punctuated distribution of GFP-mRFP-LC3
(Figure 4c). These observations thus suggest that PARP-1 activation contributes to the functional autophagy induced by $\mathrm{H}_{2} \mathrm{O}_{2}$ in $\mathrm{Bax}-/-\mathrm{Bak}-/-$ MEFs.

$\mathrm{H}_{2} \mathrm{O}_{2}$ induces AMPK activation, suppression of mTOR signaling and induction of autophagy. At present, the signaling pathway controlling ROS-mediated autophagy has not been fully understood. mTOR signaling pathway senses diverse signals from nutrients, growth factors and energy status and regulate many essential biological processes, including autophagy. ${ }^{25}$ One of the major upstream regulators of mTOR is AMPK, a critical energy sensor that can interface with various signaling molecules. ${ }^{26}$ Here we first examined the effect of $\mathrm{H}_{2} \mathrm{O}_{2}$ on $A M P K$ activation. As shown in Figure $5 \mathrm{a}, \mathrm{H}_{2} \mathrm{O}_{2}$ treatment caused a rapid and significant increase of AMPK phosphorylation at Thr-172. It is known that AMPK activates tuberous sclerosis complex 2 (TSC2) and subsequently inhibits mTOR function. ${ }^{27}$ In this study, $\mathrm{H}_{2} \mathrm{O}_{2}$ treatment induced concurrent reduction of phosphorylation of p70S6K and 4EBP1 (Figure 5a), two key downstream target of mTOR, suggesting suppression of mTOR function.
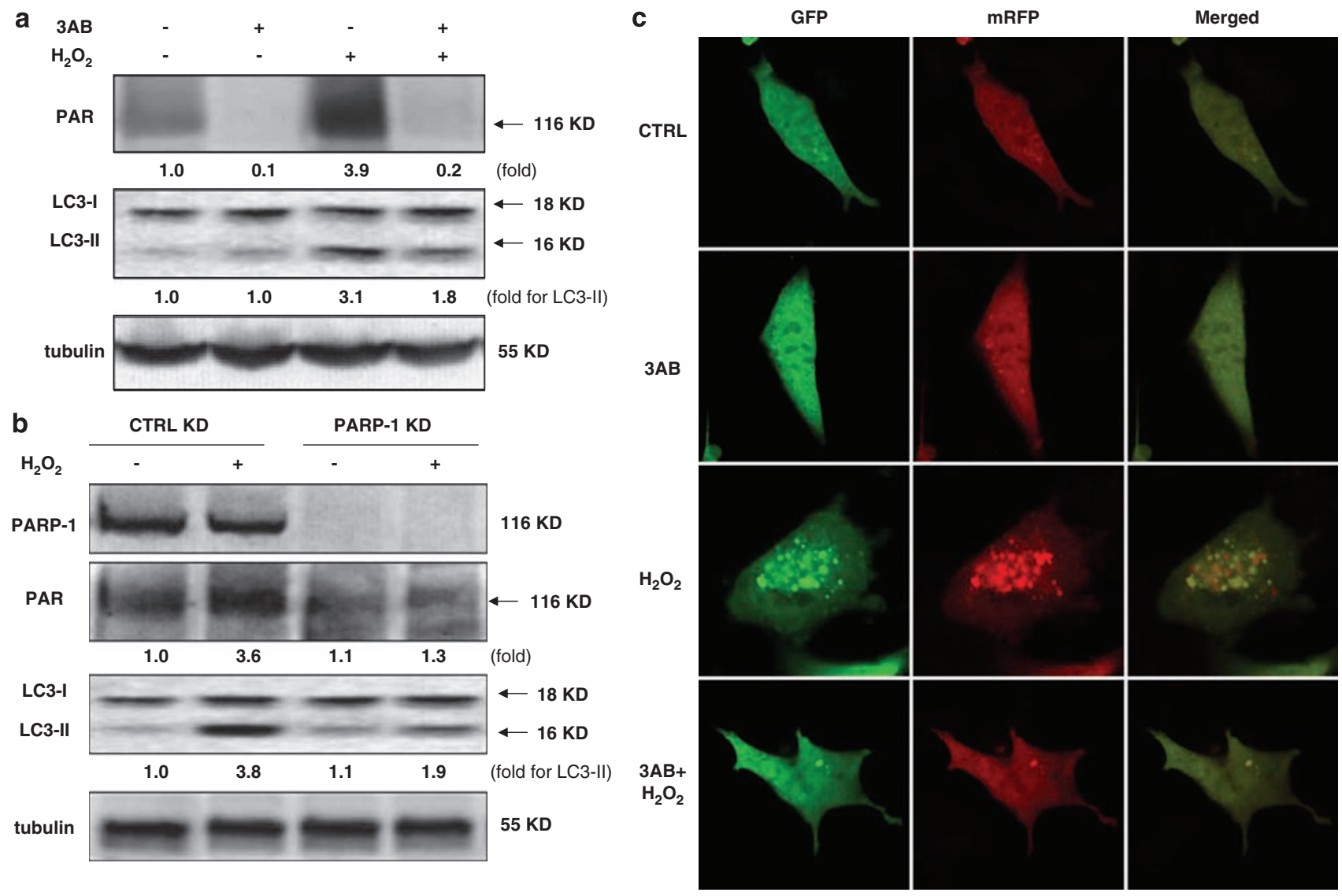

Figure 4 Poly(ADP-ribose) polymerase-1 (PARP) activation contributes to $\mathrm{H}_{2} \mathrm{O}_{2}$-induced autophagy. (a) Effect of $3 A B$ on the conversion of $L C 3-I$ to $L C 3$-II induced by $\mathrm{H}_{2} \mathrm{O}_{2}$. Cells were treated as described in Figure $2 \mathrm{c}$ and subjected to western blot for analysis. (b) Effect of PARP- 1 knockdown on $\mathrm{H}_{2} \mathrm{O}_{2}$-induced autophagy. Knockdown of PARP-1 by siRNAs was performed as described in Figure 2d. Cells were treated with $\mathrm{H}_{2} \mathrm{O}_{2}(250 \mu \mathrm{M} \times$ for $30 \mathrm{~min})$ and cell lysates were subjected to western blot. In both (a and $\mathbf{b}$ ), the protein level was quantified and the means (fold of changes over the control group) of three independent experiments were presented. (c) $3 A B$ blocked the $\mathrm{H}_{2} \mathrm{O}_{2}$ induced punctuated distribution of GFP-mRFP-LC3 protein. Cells were transfected as described in Figure $3 \mathrm{~b}$. With or without $1 \mathrm{~h}$ pretreatment of $10 \mathrm{mM} 3 \mathrm{AB}$, cells were incubated with $\mathrm{H}_{2} \mathrm{O}_{2}$ for $2 \mathrm{~h}$. The representative cells were photographed 
Next, to address whether AMPK activation plays an critical role in $\mathrm{H}_{2} \mathrm{O}_{2}$-induced autophagy, we measured the effect of AMPK suppression on $\mathrm{H}_{2} \mathrm{O}_{2}$-induced autophagy by using the following approaches: (i) treating cells with compound $\mathrm{C}$, a specific AMPK inhibitor, ${ }^{28}$ and (ii) AMPK knockdown. Compound $\mathrm{C}$ significantly suppressed $\mathrm{H}_{2} \mathrm{O}_{2}$-induced activation of AMPK and restored the phosphorylation of $\mathrm{p70S6 \textrm {K } \text { and }}$ 4EBP1. As a result, the LC3-I to LC3-II conversion induced by $\mathrm{H}_{2} \mathrm{O}_{2}$ was also blocked by compound $\mathrm{C}$ treatment (Figure $5 \mathrm{~b}$ ). Consistently, AMPK knockdown remarkably reduced endogenous expression of AMPK and reversed the inhibitory effect of $\mathrm{H}_{2} \mathrm{O}_{2}$ on p70S6K and 4EBP1 phosphorylation, and subsequently suppressed the LC3-I to LC3-II conversion (Figure $5 \mathrm{c}$ ). Compound $\mathrm{C}$ pretreatment also markedly inhibited $\mathrm{H}_{2} \mathrm{O}_{2}$-induced autophagosome formation indicated by the punctuated distribution of GFP-mRFP-LC3 (Figure 5d). It is thus believed that AMPK plays a critical role in $\mathrm{H}_{2} \mathrm{O}_{2}$ induced autophagy, most probably by suppression of mTOR.

The serine/threonine protein kinase LKB1 has been identified as the key upstream kinase of AMPK in mammalian cells in response to altered ATP/AMP ratio. ${ }^{29}$ Thus, we asked whether LKB1 is involved in $\mathrm{H}_{2} \mathrm{O}_{2}$-induced AMPK activation and subsequent autophagy induction. Here we observed that LKB1 knockdown greatly attenuated $\mathrm{H}_{2} \mathrm{O}_{2}$-induced AMPK activation, mTOR suppression and subsequent LC3-I to LC3-II conversion, while showing no effect on PAR formation (Figure 5e). Such data clearly suggest the involvement of LKB1 in $\mathrm{H}_{2} \mathrm{O}_{2}$-induced AMPK activation and autophagy induction downstream of PARP-1.

\section{PARP-1 activation contributes to the activation of AMPK} and subsequent induction of autophagy. Mammalian AMPK is sensitive to the cellular AMP/ATP ratio and is activated by metabolic stresses that inhibit ATP production or those that stimulate ATP consumption. ${ }^{30}$ Meanwhile, ROS has been reported to induce ATP depletion following excessive activation of PARP-1.4,6 Thus, we hypothesize that in cells treated with $\mathrm{H}_{2} \mathrm{O}_{2}, \mathrm{PARP}-1$ activation leads to a series of sequential events, including ATP depletion, AMPK activation, suppression of mTOR function and induction of autophagy. Here we first observed that suppression of PARP-1 function by $3 A B$ or PARP-1 knockdown markedly blocked $\mathrm{H}_{2} \mathrm{O}_{2}$-induced AMPK activation, restored the phosphorylation of p70S6K and 4EBP1, and subsequently inhibited LC3-I to LC3-II conversion (Figure 6a and b). Interestingly, suppression of AMPK activation using the chemical inhibitor, compound $\mathrm{C}$, or AMPK knockdown had no obvious effect on PAR formation (Figure $6 c$ and $d$ ). Moreover, MP pretreatment led to restoration of ATP level (Supplementary Figure 2a), attenuation of $\mathrm{H}_{2} \mathrm{O}_{2}$-induced AMPK activation, mTOR suppression and subsequent LC3-I to LC3-II conversion (Supplementary Figure 2c). Taken together, it is clear that $\mathrm{H}_{2} \mathrm{O}_{2}$-induced PARP-1 activation leads to dramatic ATP depletion, which is responsible for the subsequent AMPK activation and autophagy induction.

Autophagy serves as a cell survival mechanism to
protect against $\mathrm{H}_{2} \mathrm{O}_{2}$-induced necrotic cell death. In
this study, we attempted to determine the role of autophagy in $\mathrm{H}_{2} \mathrm{O}_{2}$-induced necrotic cell death in Bax-/Bak-/- MEFs through modulation of autophagy. First, autophagy was blocked by knockdown of ATG5 and ATG7, two key ATGs involved in autophagosome elongation stage. LC3-I to LC3-II conversion induced by $\mathrm{H}_{2} \mathrm{O}_{2}$ was markedly blocked by the knockdown of ATG5 or ATG7 (Figure 7a). Consistently, the knockdown of ATG5 or ATG7 almost completely abolished $\mathrm{H}_{2} \mathrm{O}_{2}$-induced punctuated distribution of GFP-mRFP-LC3 (Figure 7b). It is interesting to note that knockdown of ATG5 or ATG7 significantly sensitized $\mathrm{H}_{2} \mathrm{O}_{2}$ induced cell death, while mitigated ETO-mediated cell death (Figure 7c). It thus suggests that autophagy plays a protective role in $\mathrm{H}_{2} \mathrm{O}_{2}$-induced cell death, while ETOinduced cell death is likely to be autophagy-dependent, being consistent with the previous report. ${ }^{12}$ Second, we examined the effect of LKB1 and AMPK suppression on $\mathrm{H}_{2} \mathrm{O}_{2}$-induced cell death. As shown in Figure 8a, knockdown of LKB1 greatly sensitized $\mathrm{H}_{2} \mathrm{O}_{2}$-induced cell death. Consistently, suppression of AMPK activation by compound $\mathrm{C}$ or AMPK knockdown markedly enhanced $\mathrm{H}_{2} \mathrm{O}_{2}$-induced cell death (Figure $8 \mathrm{~b}$ and $\mathrm{c}$ ). As these approaches are known to block $\mathrm{H}_{2} \mathrm{O}_{2}$-induced autophagy (Figure $5 \mathrm{~b}$, c and e), such findings further strengthen the notion that autophagy plays a prosurvival function in $\mathrm{H}_{2} \mathrm{O}_{2}$-induced cell death. Lastly, we analyzed the effect of autophagy induction on $\mathrm{H}_{2} \mathrm{O}_{2}$-induced cell death. Rapamycin has been well established as an autophagy inducer through its specific inhibitory effect on mTOR. ${ }^{31}$ As shown in Figure 8d, treatment with rapamycin almost completely blocked mTOR function demonstrated by the reduction of the phosphorylation level of p70S6K and 4EBP1 and promoted LC3-I to LC3-II conversion. As expected, rapamycin treatment protected cell death induced by $\mathrm{H}_{2} \mathrm{O}_{2}$ effectively (Figure $8 \mathrm{e}$ ). Taken together, these results indicate that autophagy acts as a cell survival mechanism in $\mathrm{H}_{2} \mathrm{O}_{2}$-induced cell death.

\section{Discussion}

In this study we identify a novel function of PARP-1 in mediating $\mathrm{H}_{2} \mathrm{O}_{2}$-induced autophagy through the AMPKmTOR pathway, and such autophagy plays a prosurvival function in ROS-induced necrosis. As PARP-1 has been well established in oxidative stress-mediated necrosis through ATP depletion, ${ }^{4}$ it appears that PARP-1 is able to elicit dual pathways with opposite functions in response to oxidative stress, as illustrated in Figure 8f. The decision of live or death is depending on the balance between autophagy and necrosis mediated by these two distinct pathways.

Oxidative DNA damage includes modifications to bases and the sugar phosphates, as well as single- or double-strand DNA breaks. ${ }^{32}$ Such damage leads to PARP-1 activation, intracellular NAD + depletion, suppression of ATP production and finally cell death, especially necrotic cell death. ${ }^{4}$ Furthermore, overactivation of PARP-1 produces large quantities of PAR polymers, leading to the translocation of apoptosis-inducing factor from mitochondria to the nucleus, where it causes chromatin condensation and DNA fragmentation and subsequent programmed necrotic cell death independent of the caspase cascade. ${ }^{5,33}$ Currently, there is little understanding regarding the involvement of PARP-1 
activation in autophagy, although one earlier study reported that the formation of autophagic bodies in macrophages occurs downstream of PARP-1 activation. ${ }^{16}$ In this regard, results from this study expand the functional scope of PARP-1 by revealing a novel signaling pathway linking PARP-1 to autophagy through activation of LKB1-AMPK and subsequent suppression of mTOR function.

The AMPK is known to work as a fuel gauge and as a master switch in regulating glucose and lipid metabolism. ${ }^{26,30}$ Despite of the initial controversy, the emerging evidence has clearly supported the notion that AMPK is a critical regulatory molecule in promoting autophagy in mammalian cells. ${ }^{34}$ At present, the upstream regulatory mechanisms controlling AMPK activation are poorly understood. LKB1 has been identified as the key upstream kinase of AMPK in mammalian cells in response to altered ATP/AMP ratio. ${ }^{29}$ In addition, AMP has been proposed to contribute to the activation of AMPK by direct allosteric activation and by protecting Thr172 from dephosphorylation. $^{35}$ In this study, we demonstrate that PARP-1 acts upstream of AMPK through ATP depletion and
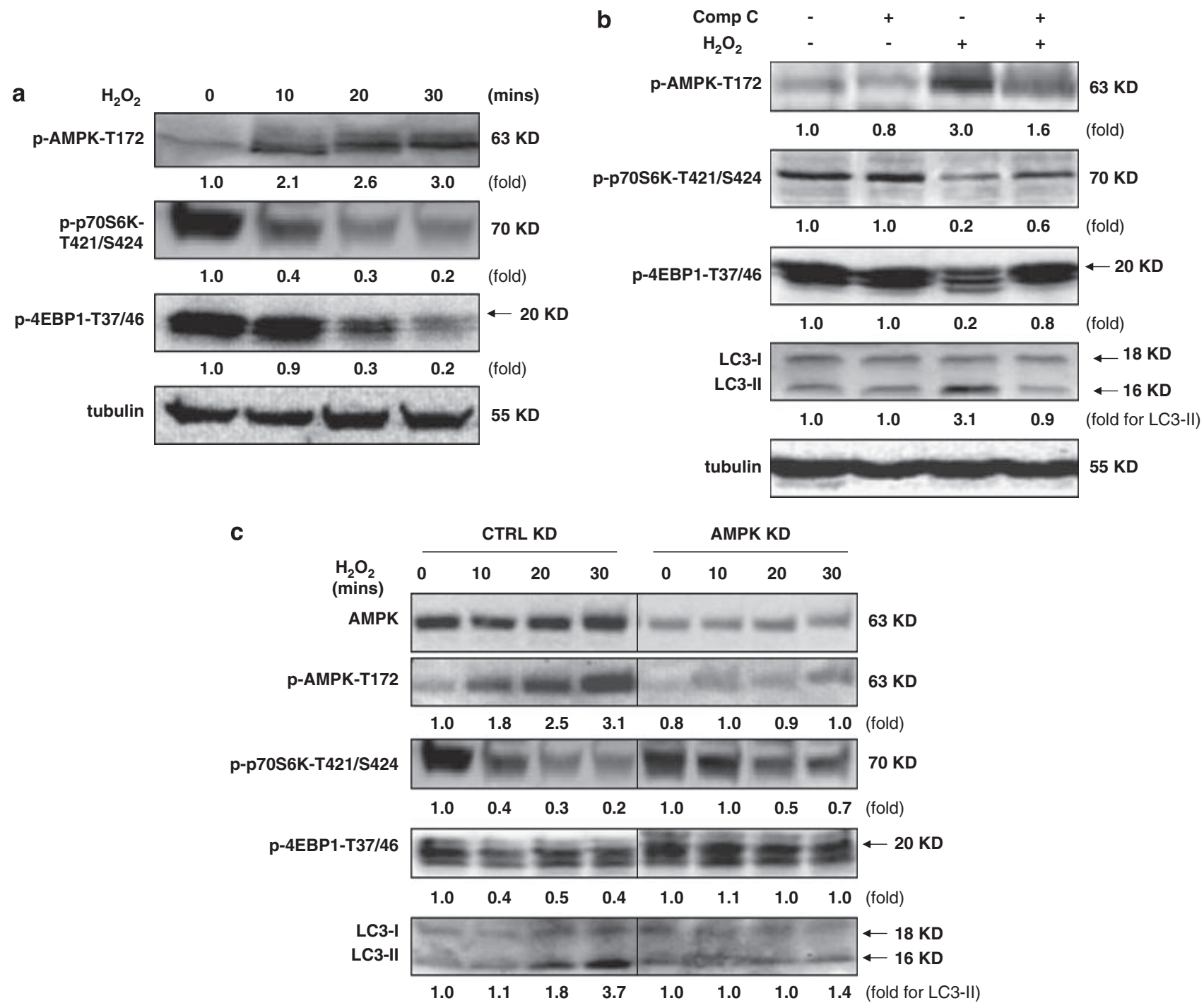

tubulin

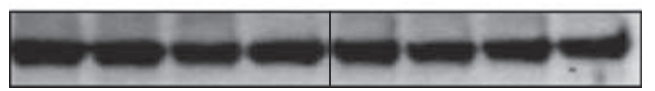

$55 \mathrm{KD}$

Figure 5 The AMPK activation results in suppression of mTOR function and induction of autophagy by $\mathrm{H}_{2} \mathrm{O}_{2}$. (a) Effect of $\mathrm{H}_{2} \mathrm{O}_{2}$ on AMPK-mTOR signaling. Cells were treated with $\mathrm{H}_{2} \mathrm{O}_{2}(250 \mu \mathrm{M})$ for $10,20,30 \mathrm{~min}$, and cell lysates were subjected to western blot. (b) Compound $\mathrm{C}$, a specific AMPK inhibitor, reversed the effect of $\mathrm{H}_{2} \mathrm{O}_{2}$ on AMPK-mTOR signaling. Cells were treated with $\mathrm{H}_{2} \mathrm{O}_{2}(250 \mu \mathrm{M})$ for $30 \mathrm{~min}$ with or without $1 \mathrm{~h}$ pretreatment of compound $\mathrm{C}(10 \mu \mathrm{M})$, and cell lysates were subjected to western blot. (c) AMPK knockdown blocked the inhibitory effect of $\mathrm{H}_{2} \mathrm{O}_{2}$ on mTOR function and induction of autophagy. Knockdown of AMPK expression by siRNAs was performed as described in Materials and Methods. After $72 \mathrm{~h}$ of siRNA transfection, cells were treated with $\mathrm{H}_{2} \mathrm{O}_{2}(250 \mu \mathrm{M})$ for $10,20,30$ min. Cell lysates were the subjected to western blot. (d) Compound $\mathrm{C}$ blocked the $\mathrm{H}_{2} \mathrm{O}_{2}$-induced punctuated distribution of GFP-mRFP-LC3 protein. Cells were transfected as described in Figure $3 \mathrm{~b}$. With or without $1 \mathrm{~h}$ pretreatment of $10 \mu \mathrm{M}$ compound C, cells were incubated with $\mathrm{H}_{2} \mathrm{O}_{2}$ for $2 \mathrm{~h}$. The cells were examined and photographed. (e) LKB1 knockdown attenuated $\mathrm{H}_{2} \mathrm{O}_{2}$-induced AMPK activation, and subsequent induction of autophagy. Knockdown of LKB1 expression by siRNAs was performed as described in Materials and Methods. After $72 \mathrm{~h}$ of siRNA transfection, cells were treated with $\mathrm{H}_{2} \mathrm{O}_{2}(250 \mu \mathrm{M})$ for $10,20,30 \mathrm{~min}$. Cell lysates were subjected to western blot. In $(\mathbf{a}, \mathbf{b}, \mathbf{c}$ and $\mathbf{e})$, the protein level was quantified and the means (fold of changes over the control group) of three independent experiments were presented 
reduced ATP/AMP ratio. One recent study revealed that AMPK promotes PARP activity through direct phosphorylation in intestinal epithelial cells, ${ }^{36}$ suggesting a possible positive-feedback loop between these two key molecules in determining the cellular response to stress factors such as oxidative stress and DNA damage. d
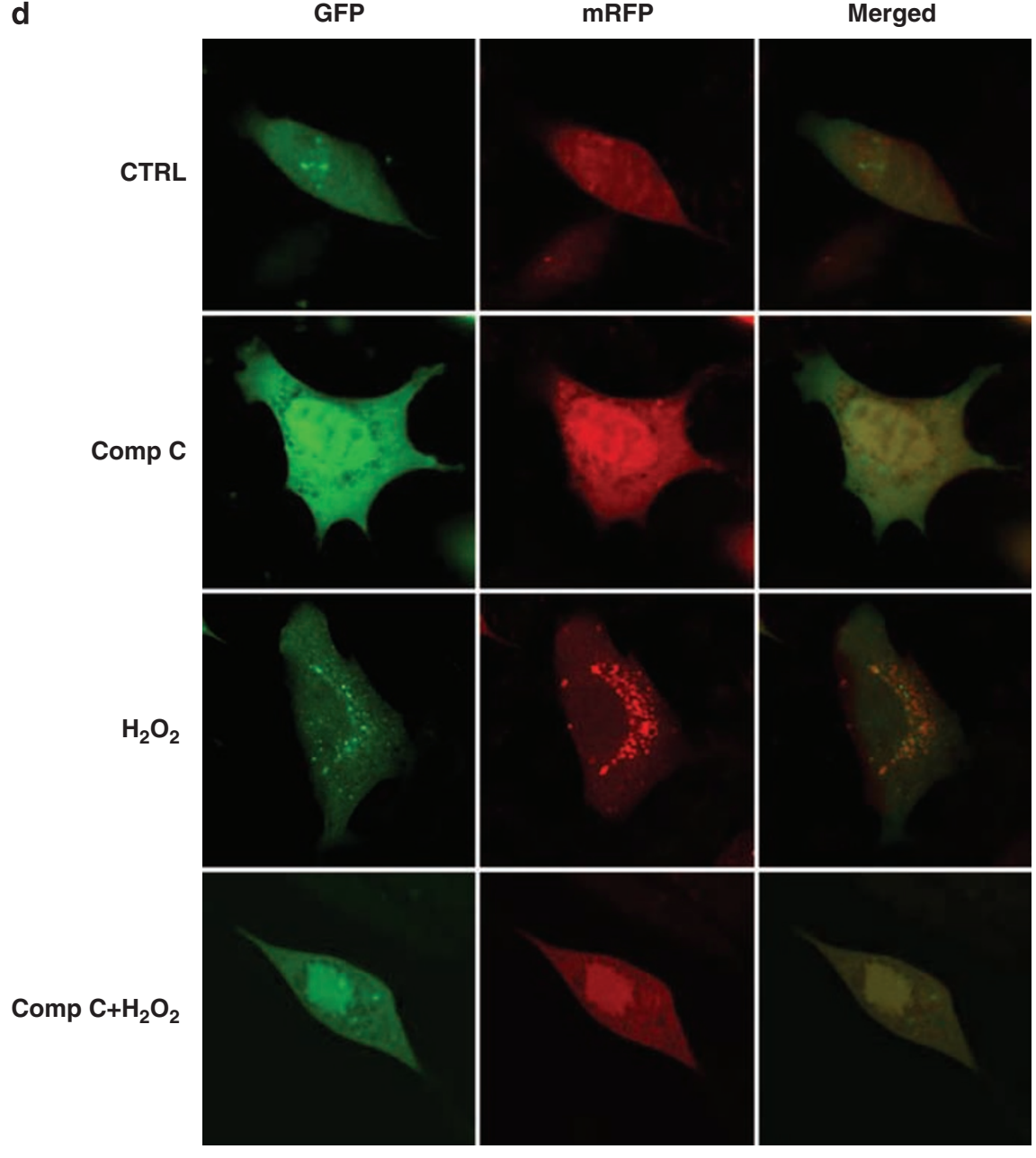

e

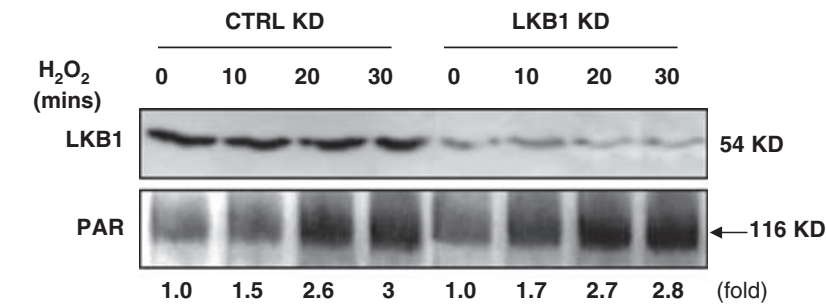

p-AMPK-T172
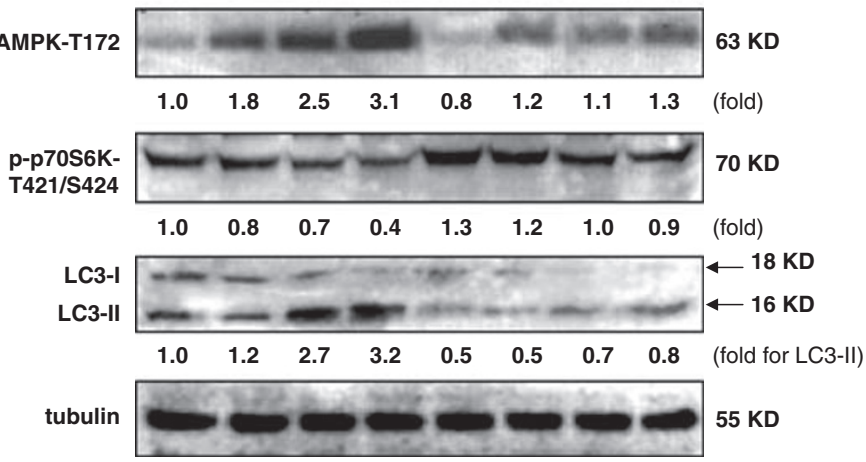

Figure 5 continued 
a
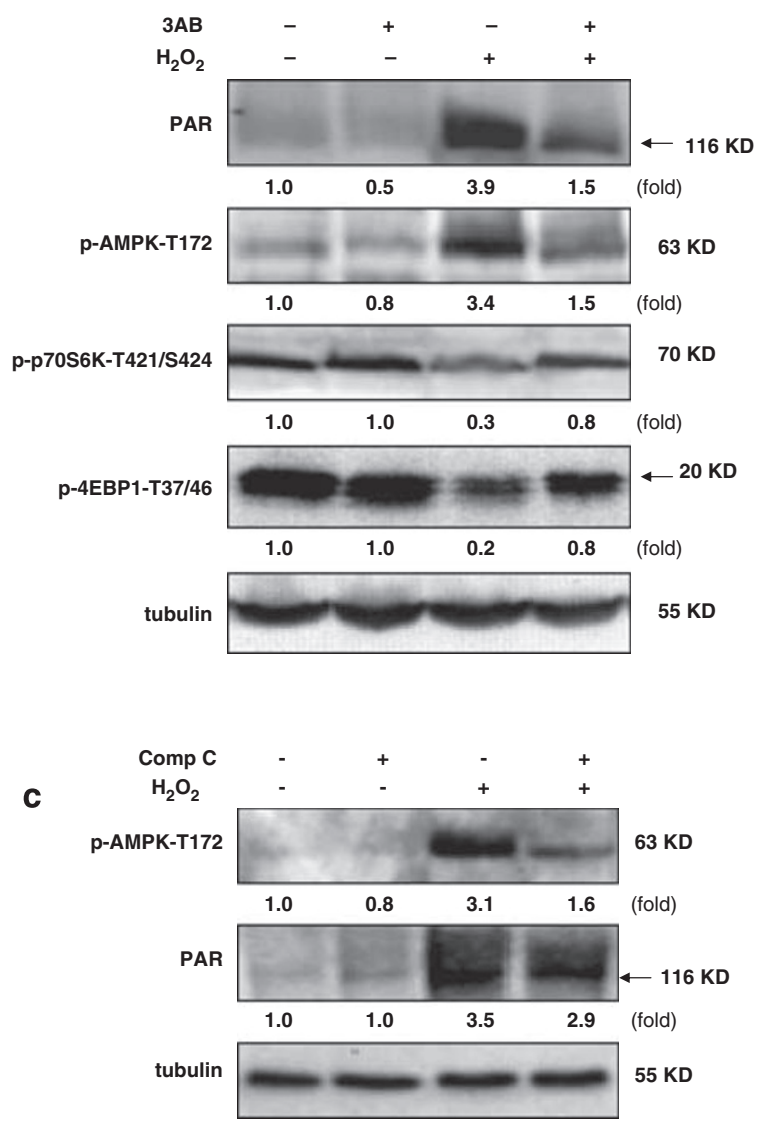

b
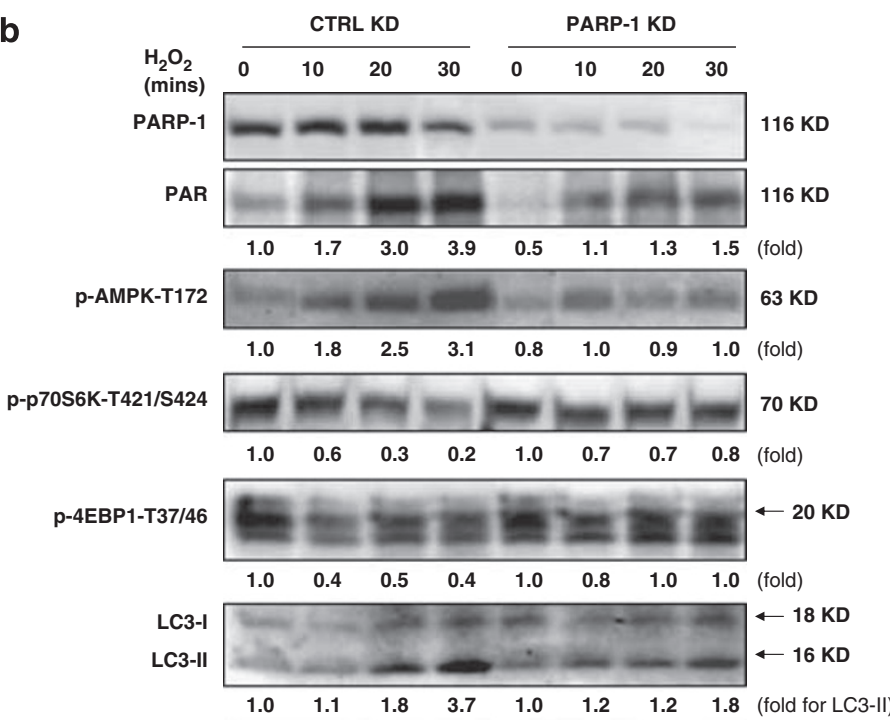

tubulin $55 \mathrm{KD}$

d

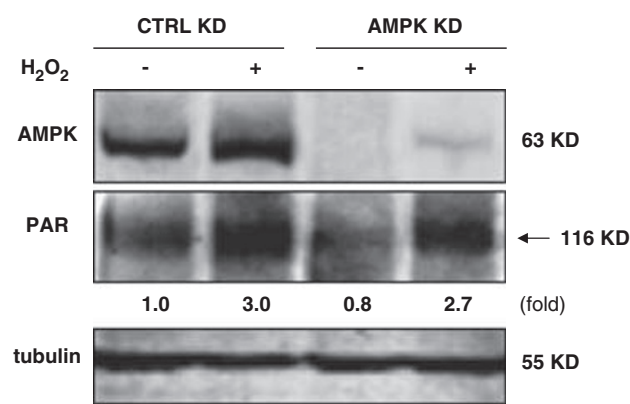

Figure 6 Poly(ADP-ribose) polymerase-1 (PARP-1) activation contributes to $\mathrm{H}_{2} \mathrm{O}_{2}$-induced AMPK activation. (a) Effect of $3 A B$ on AMPK and mTOR. Cells were treated as described in Figure 2c and subjected to western blot for analysis. (b) Effect of PARP-1 knockdown on AMPK and mTOR as well as on autophagy in cells treated with $\mathrm{H}_{2} \mathrm{O}_{2}$. Knockdown of PARP-1 was performed as described in Materials and Methods. Cells were treated with $\mathrm{H}_{2} \mathrm{O}_{2}(250 \mu \mathrm{M})$ for designated periods and subjected to western blot. (c) Effect of compound $\mathrm{C}$ on $\mathrm{H}_{2} \mathrm{O}_{2}$-induced PARP-1 activation. Cells were treated as described in Figure $5 \mathrm{~b}$ and subjected to western blot. (d) Effect of AMPK knockdown on $\mathrm{H}_{2} \mathrm{O}_{2}$-induced PARP-1 activation. After AMPK knockdown, cells were treated with $\mathrm{H}_{2} \mathrm{O}_{2}(250 \mu \mathrm{M} \times$ for $30 \mathrm{~min})$ and subjected to western blot. The protein level was quantified and the means (fold of changes over the control group) of three independent experiments were presented

On the other hand, it has been described that AMPK activation mediates the activation of TSC1 and 2, and the subsequent inhibition of GTP-binding protein Ras homolog enriched in brain (Rheb), and eventually the suppression of mTOR function. ${ }^{25,27} \mathrm{~A}$ very recent study revealed that AMPK inhibition of mTOR function can be reinforced through phosphorylation of the essential mTORC1 subunit, raptor. ${ }^{37}$ As mTOR has been well established as a key negative regulator for autophagy, it is reasonable to postulate that in cells under oxidative stress AMPK activation leads to autophagy through suppression of mTOR function. Such a notion is supported by the effect of rapamycin on $\mathrm{H}_{2} \mathrm{O}_{2}$ induced LC3-I to II conversion (Figure 8d) and cell death (Figure $8 \mathrm{e}$ ), although currently we do not have any genetic evidence to establish the role of mTOR in $\mathrm{H}_{2} \mathrm{O}_{2}$-induced autophagy. Interestingly, similar mechanisms were also found when U2OS cells were treated with avicin D, a plant triterpenoid for induction of autophagy as a cell death mechanism. ${ }^{38}$ It is believed that understanding of the signaling pathway of PARP-1-LKB1-AMPK-mTOR-autophagy provides directions for the development of new therapeutic strategies for human diseases such as cancer. In fact, activation of LKB1-AMPK pathway has been found to delay the tumorigenesis process in PTEN heterozygous mice. ${ }^{39}$ Similarly, targeting mTOR pathway through activation of AMPK has been considered as an additional therapeutic strategy for breast cancer intervention. ${ }^{40}$

After establishing the signaling pathway in ROS-mediated autophagy, we then examined the functional role of autophagy in ROS-mediated necrosis. Data from this study clearly suggest that autophagy is a cell survival mechanism in $\mathrm{H}_{2} \mathrm{O}_{2}$-induced cell death, based on the observations that suppression of autophagy by knockdown of ATGs sensitized, whereas activation of autophagy by rapamycin protected $\mathrm{H}_{2} \mathrm{O}_{2}$-induced cell death (Figures 7 and 8). Our data are found to be consistent with the earlier report that ROS-mediated the prosurvival autophagy during starvation. ${ }^{15}$ At present, there is growing understanding that autophagy is a protective mechanism under stress conditions, especially with evidence from a series of in vivo studies in which autophagy is found to inhibit necrotic cell death of cancer cells under metabolic stress. ${ }^{41,42}$ On the other hand, a number of earlier studies 
a
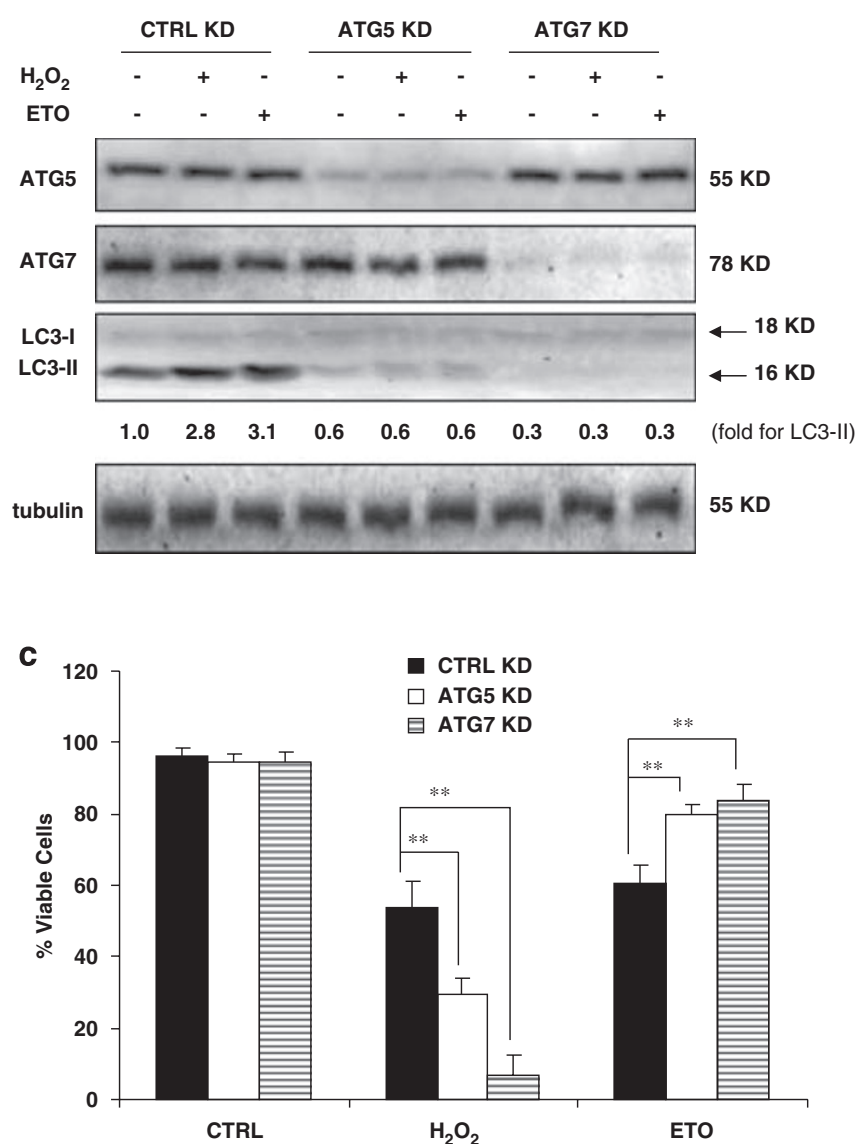

b



Figure 7 Knockdown of ATG blocks $\mathrm{H}_{2} \mathrm{O}_{2}$-induced autophagy and sensitizes cell death. (a) ATG5 and ATG7 knockdown blocked LC3-I to LC3-II conversion induced by $\mathrm{H}_{2} \mathrm{O}_{2}$ or etoposide. Knockdown of ATG5 and ATG7 expression by siRNAs was performed as described in Materials and Methods. After $72 \mathrm{~h}$ of siRNA transfection, cells were treated with $\mathrm{H}_{2} \mathrm{O}_{2}(250 \mu \mathrm{M} \times$ for $4 \mathrm{~h})$ or etoposide $(20 \mu \mathrm{M} \times$ for $4 \mathrm{~h})$, and subjected to western blot. The protein level was quantified and the means (fold of changes over the control group) of three independent experiments were presented. (b) ATG5 and ATG7 knockdown suppressed the punctuated distribution of GFP-mRFP-LC3 induced by $\mathrm{H}_{2} \mathrm{O}_{2}$. After $48 \mathrm{~h}$ of siRNA transfection, cells were transfected with GFP-mRFP-LC3 plasmid. After $24 \mathrm{~h}$, cells were treated with $\mathrm{H}_{2} \mathrm{O}_{2}(250 \mu \mathrm{M} \times$ for $2 \mathrm{~h})$ and observed by confocal microscopy. (c) Effect of ATG5 and ATG7 knockdown on cell death induced by $\mathrm{H}_{2} \mathrm{O}_{2}$ or etoposide. After transfected with siRNA for $72 \mathrm{~h}$, cells were treated with $\mathrm{H}_{2} \mathrm{O}_{2}$ $(250 \mu \mathrm{M} \times$ for $24 \mathrm{~h})$ or etoposide $(20 \mu \mathrm{M} \times$ for $48 \mathrm{~h})$, and subjected to PI exclusion test coupled with flow cytometry for the detection of cell survival. Data were presented as means \pm S.D. from three independent experiments $\left({ }^{* \star} P<0.01, t\right.$-test)

have demonstrated that autophagy serves as a cell killing mechanism in ROS-mediated caspase-independent cell death. ${ }^{16,17}$ Such a discrepancy in the literature is likely due to the different cell systems used or even different interpretation of the data. For example, we have recently unraveled that autophagy serves as a cell survival mechanism in zVADinduced necrotic cell death in mouse fibrosarcoma L929 cells, ${ }^{18}$ thus directly challenged the earlier notion that $\mathrm{ZVAD}$ induces autophagic cell death in the same system. ${ }^{43}$ Therefore, we should excise cautions in defining the role of autophagy in cell death, particularly in necrosis.

One intriguing finding of this study is that suppression of autophagy by ATG5 and ATG7 knockdown blocked the cell death induced by ETO, in contrast to the effect on $\mathrm{H}_{2} \mathrm{O}_{2}$ induced cell death (Figure 7c). This is in fact consistent with the previous report that ETO-induced cell death in Bax-/Bak-/- MEFs is autophagy-dependent. ${ }^{12}$ At present, the underlying mechanism contributing to the different role of autophagy in $\mathrm{H}_{2} \mathrm{O}_{2}$ and ETO-induced cell death remains elusive. One possibility is that, although both $\mathrm{H}_{2} \mathrm{O}_{2}$ and ETO cause DNA damage, they engage PARP-1 activation in a different pattern: $\mathrm{H}_{2} \mathrm{O}_{2}$-induced PARP-1 activation is fast and strong (Figure 2a), whereas ETO only induced mild PARP-1 activation (data not shown). Consequently, there is evident ATP depletion and AMPK activation in $\mathrm{H}_{2} \mathrm{O}_{2}$-treated cells (Figures 2 and 5), but not in cells treated with ETO (data not shown). Interestingly, the effects of $\mathrm{H}_{2} \mathrm{O}_{2}$ found in this study are strikingly similar to that of DNA alkylating agents. First, these DNA alkylating agents such as $N$-methyl- $N$-nitro- $N$ nitrosoguanidine are known to induce necrosis through activation of PARP-1. ${ }^{21,44}$ Second, autophagy acts as a survival mechanisms in cells treated with DNA alkylating agents, based on observations that suppression of autophagy by $\mathrm{CQ}$ or ATG5 knockdown enhanced tumor cell death in animals treated with the DNA alkylating drug. ${ }^{45}$ Thus, we speculate that different forms of DNA damage induced by 
distinct groups of DNA damage agents would engage autophagy differently, depending on the status of PARP-1 activation. Future work towards this direction will certainly yield valuable information in understanding the role of autophagy in response to DNA damage and in development of effective cancer therapeutic strategy through modulation of autophagy.

In summary, we demonstrate a novel function of PARP-1 in regulation of oxidative stress-induced autophagy through the LKB1-AMPK-mTOR signaling pathway and such autophagy serves as a cell survival mechanism against ROS-mediated necrosis. These findings are believed to bear important implications for understanding the complex relationship among oxidative stress, autophagy and cell death.

\section{Materials and Methods}

Cell culture. Immortalized wt MEFs and Bax-/- Bak-/- MEFs were kindly provided by Emily H-Y Cheng (Washington University, St. Louis, USA) and cultured in Dulbecco's modified Eagle's medium supplemented with $10 \%$ fetal bovine serum (Hyclone) in a $5 \% \mathrm{CO}_{2}$ atmosphere at $37^{\circ} \mathrm{C}$.

Reagents. Hydrogen peroxide, $3 A B, E T O$, rapamycin, cycloheximide $(\mathrm{CHX})$, MP, PI, ATP detection kit and anti-tubulin antibody were purchased from Sigma (St. Louis, MO, USA). The specific AMPK inhibitor compound C was from Calbiochem (San Diego, CA, USA). Pan-caspase inhibitor z-VAD-FMK was purchased from BioMol (Plymouth meeting, PA, USA). Antibodies against phosphop70S6K, phospho-AMPK, phospho-4EBP1 were purchased from Cell Signaling (Beverly, MA, USA); anti-PARP-1 and anti-PAR antibody were from BD Pharmingen (Los Angeles, CA, USA). Antibody against LC3 was purchased from Abgent (San Diego, CA, USA). Mouse recombinant TNF- $\alpha$ was obtained from R\&D (Minneapolis, MN, USA). Mouse AMPK $\alpha$ siRNA was purchased from Santa Cruz (Santa Cruz, CA, USA). Mouse PARP, LKB1, Atg5 and Atg7 siRNA were from Dharmacon Inc. (Lafayette, CO, USA). The GFP-mRFP-LC3 plasmid was kindly provided by Dr. T Yoshimori (Osaka Uniersity, Japan).

Detection of cell death. Cell death was determined using the live cell PI exclusion test coupled with flow cytometry. In brief, cells were trypsinized at the end of the experiments. Cells were washed once with phosphate buffer saline (PBS) and
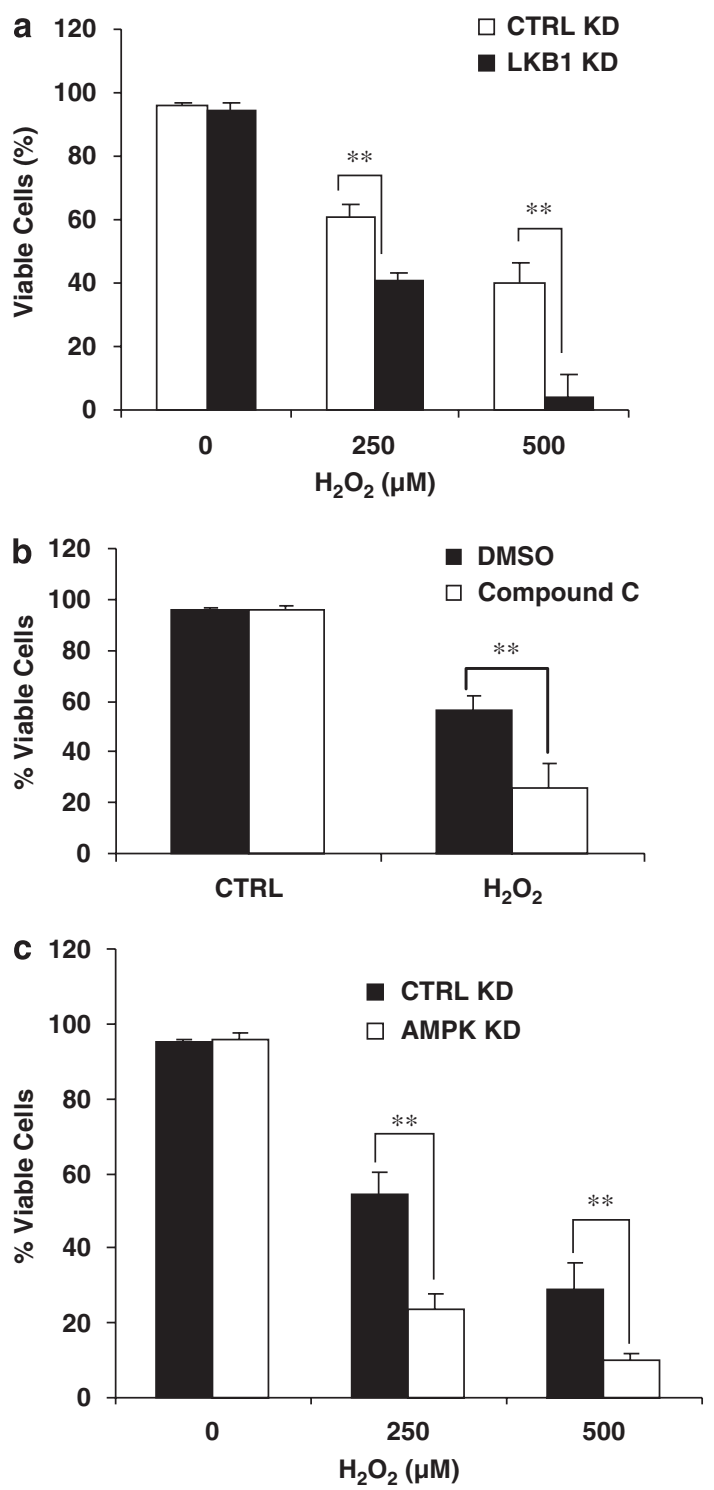

Figure 8 continued
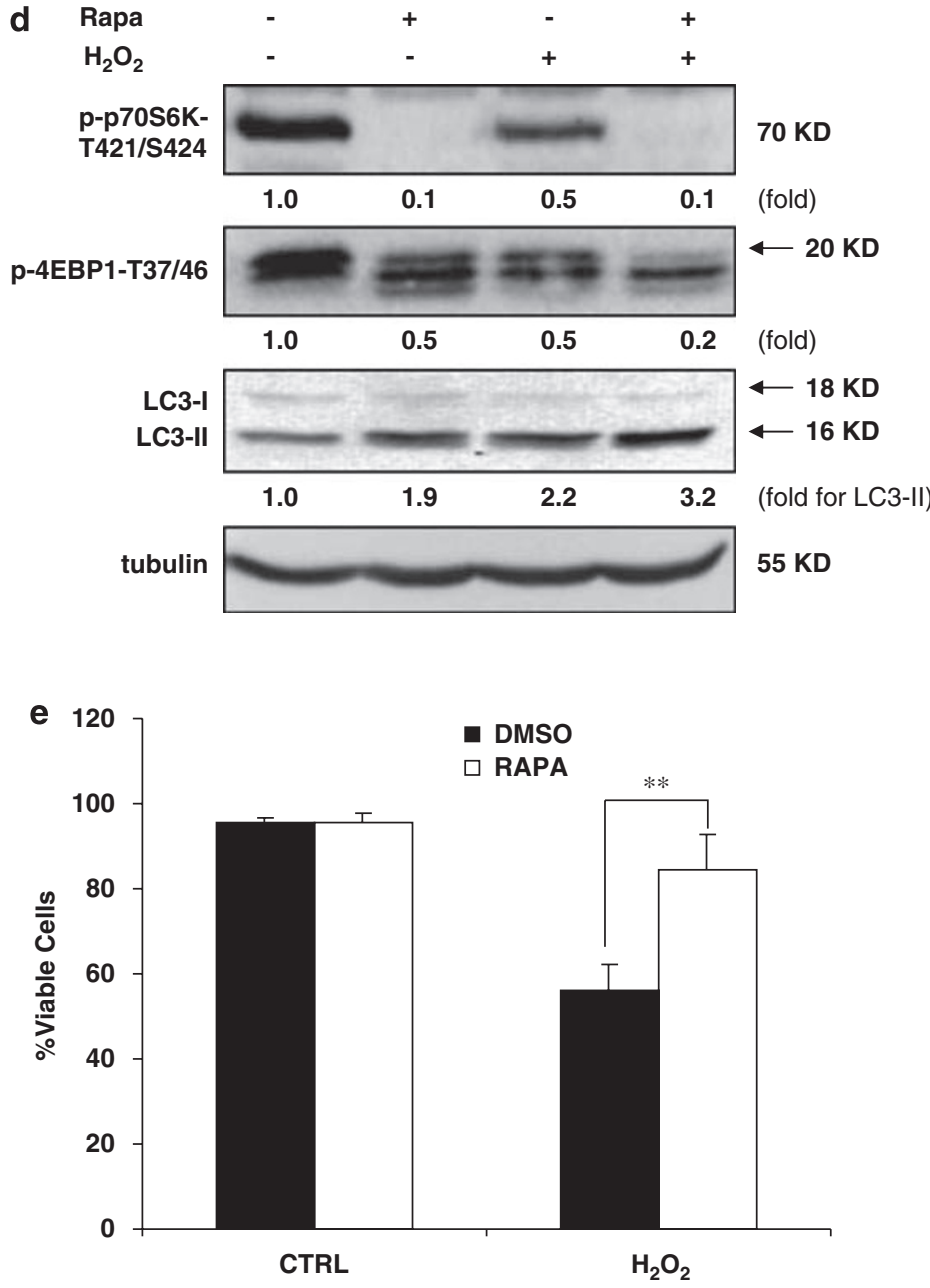


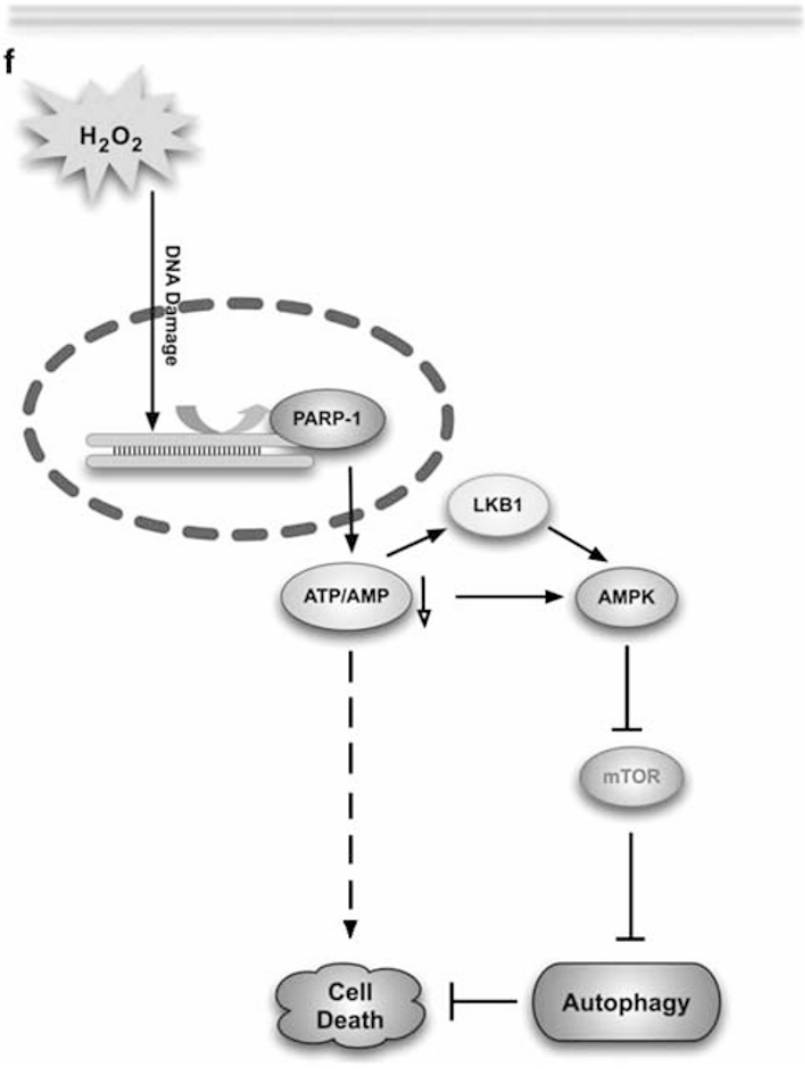

Figure 8 Autophagy serves as a cell survival mechanism to protect against $\mathrm{H}_{2} \mathrm{O}_{2}$-induced necrotic cell death. (a) Knockdown of LKB1 sensitized $\mathrm{H}_{2} \mathrm{O}_{2}$-induced cell death. After transfection with LKB1 siRNA for $72 \mathrm{~h}$, cells were treated with $\mathrm{H}_{2} \mathrm{O}_{2}$ $(250 \mu \mathrm{M} \times$ for $24 \mathrm{~h}$ ) and subjected to $\mathrm{Pl}$ exclusion test. (b) Compound $\mathrm{C}$ sensitized $\mathrm{H}_{2} \mathrm{O}_{2}$-induced cell death. Cells were incubated with $\mathrm{H}_{2} \mathrm{O}_{2}(250 \mu \mathrm{M} \times$ for $24 \mathrm{~h})$ with or without the pretreatment of $10 \mu \mathrm{M}$ compound $\mathrm{C}$. Cell survival was determined using PI exclusion test. (c) Knockdown of AMPK sensitized $\mathrm{H}_{2} \mathrm{O}_{2}$-induced cell death. After transfection with AMPK siRNA for $72 \mathrm{~h}$, cells were treated with $\mathrm{H}_{2} \mathrm{O}_{2}$ $(250 \mu \mathrm{M} \times$ for $24 \mathrm{~h}$ ) and subjected to $\mathrm{Pl}$ exclusion test. (d) The effect of rapamycin on $\mathrm{H}_{2} \mathrm{O}_{2}$-induced autophagy. Cells were treated with $\mathrm{H}_{2} \mathrm{O}_{2}(250 \mu \mathrm{M} \times$ for $30 \mathrm{~min})$ with or without $1 \mathrm{~h}$ pretreatment of rapamycin $(10 \mathrm{nM})$ and cell lysates were collected for western blot. The protein level was quantified and the means (fold of changes over the control group) of three independent experiments were presented. (e) The effect of rapamycin on $\mathrm{H}_{2} \mathrm{O}_{2}$-induced cell death. Following the same treatment as described above, percentage of viable cells was determined using the $\mathrm{PI}$ exclusion test. Data were presented as means \pm S.D. from three independent experiments $\left({ }^{\star \star} P<0.01, t\right.$-test). (f) An illustration showing the proposed effect of PARP-1 activation in $\mathrm{H}_{2} \mathrm{O}_{2}$-induced autophagy and cell death

resuspended in PBS containing $1 \mu \mathrm{g}$ of $\mathrm{Pl} / \mathrm{ml}$. The levels of $\mathrm{PI}$ incorporation were quantified by flow cytometry using a FACSCalibur flow cytometer. Cell size was evaluated by forward-angle light scattering. PI-negative cells with normal size were considered to be live cells.

Western blotting. After designated treatment, cells were collected and washed once in PBS. Cell pellets were lysed in lysis buffer $(50 \mathrm{mM}$ Tris- $\mathrm{HCl}, \mathrm{pH} 7.4$, $1 \% \mathrm{NP}-40,0.25 \%$ sodium deoxycholate, $150 \mathrm{mM} \mathrm{NaCl}, 1 \mathrm{mM}$ EGTA, $1 \mathrm{mM}$ PMSF, $1 \mathrm{mM} \mathrm{Na}_{3} \mathrm{VO}_{4}, 1 \mathrm{mM} \mathrm{NaF}$ ) with protease inhibitor cocktail (Roche). Aliquots of the lysates were subjected to SDS-PAGE and transferred to polyvinylidene-fluoride membrane (Bio-Rad). The membrane was probed with primary antibody followed by second antibody and visualized using the SuperSignal ${ }^{\mathbb{R}}$ West Dura kit (Pierce, Rockford, IL, USA), according to the manufacturer's protocol. Quantification results for the western blot were obtained using Kodak 1D 3.5 Software. The mean values indicated in the figures were from three independent experiments, as the fold of change over the control.
ATP measurement. Intracellular ATP was extracted from cells in the exponential phase of growth and measured by the luciferin/luciferase method using a bioluminescent somatic cell assay kit (Sigma), in accordance with the manufacturer's protocol. In brief, at the end of experiments, cells were collected using ice-cold cell dissociation solution (Sigma) and resuspended in ice-cold PBS $(\mathrm{pH}=7.8)$. Cells were incubated with freshly prepared ATP assay mix and ATP releasing reagent and subjected to bioluminescent detection. The ATP level was presented as percentage to the untreated control group.

Transient siRNA transfection. Cells were transfected with $100 \mathrm{nM} \mathrm{Atg5}$, Atg7, Beclin, PARP, AMPK $\alpha$ and a non-targeting siRNA control using DharmaFECT ${ }^{\mathrm{TM}} 4$ siRNA Transfection Reagent (Dharmacon) according to the supplier's protocol. After $72 \mathrm{~h}$ of transfection, cells were treated as designated.

Transient transfection and confocal microscopy analysis. Cells $\left(1 \times 10^{6}\right)$ were transfected with $1 \mu \mathrm{g}$ of the GFP-mRFP-LC3 expression plasmid using the Amaxa electroporation system, according to the supplier's protocol (kit $\mathrm{V}$, program U-20). After $24 \mathrm{~h}$, cells were treated as designated. The transfected cells were observed using a confocal microscope (Olympus Fluoview 2000).

Statistics. The results obtained from each experiment are expressed as mean \pm standard deviation (S.D.) of triplicates. The significance level was set at $P<0.05$ for each analysis using student's $t$-test.

Acknowledgements. We thank Drs. Emily Cheng, T Yoshimori and Koh Ono for reagents, and V Tergaonkar and ET Wong for helpful discussion and suggestions. Q Huang is supported by the Toxicology Program, Office of Life Science, NUS and YT Wu is supported by a NUS scholarship. The research work was also partly supported by research grants from the National Medical Research Council (NMRC) and Biomedical Research Council (BMRC), Singapore.

1. Halliwell B. Biochemistry of oxidative stress. Biochem Soc Trans 2007; 35: 1147-1150.

2. Gardner AM, Xu FH, Fady C, Jacoby FJ, Duffey DC, Tu Y et al. Apoptotic vs. nonapoptotic cytotoxicity induced by hydrogen peroxide. Free Radic Biol Med 1997; 22: 73-83.

3. Jagtap P, Szabo C. Poly(ADP-ribose) polymerase and the therapeutic effects of its inhibitors. Nat Rev Drug Discov 2005; 4: 421-440.

4. Ha HC, Snyder SH. Poly(ADP-ribose) polymerase is a mediator of necrotic cell death by ATP depletion. Proc Natl Acad Sci USA 1999; 96: 13978-13982.

5. Yu SW, Wang $\mathrm{H}$, Poitras MF, Coombs $\mathrm{C}$, Bowers WJ, Federoff $\mathrm{HJ}$ et al. Mediation of poly(ADP-ribose) polymerase-1-dependent cell death by apoptosis-inducing factor Science 2002; 297: 259-263.

6. Zhang S, Lin Y, Kim YS, Hande MP, Liu ZG, Shen HM. c-Jun N-terminal kinase mediates hydrogen peroxide-induced cell death via sustained poly(ADP-ribose) polymeraseactivation. Cell Death Differ 2007; 14: 1001-1010.

7. Klionsky DJ, Emr SD. Autophagy as a regulated pathway of cellular degradation. Science 2000; 290: 1717-1721

8. Mizushima N, Levine B, Cuervo AM, Klionsky DJ. Autophagy fights disease through cellular self-digestion. Nature 2008; 451: 1069-1075.

9. Codogno P, Meijer AJ. Autophagy and signaling: their role in cell survival and cell death Cell Death Differ 2005; 12 (Suppl 2): 1509-1518.

10. Maiuri MC, Zalckvar E, Kimchi A, Kroemer G. Self-eating and self-killing: crosstalk between autophagy and apoptosis. Nat Rev Mol Cell Biol 2007; 8: 741-752.

11. Gozuacik D, Kimchi A. Autophagy and cell death. Curr Top Dev Biol 2007; 78: 217-245.

12. Shimizu S, Kanaseki T, Mizushima N, Mizuta T, Arakawa-Kobayashi S, Thompson CB et al. Role of Bcl-2 family proteins in a non-apoptotic programmed cell death dependent on autophagy genes. Nat Cell Biol 2004; 6: 1221-1228.

13. Scherz-Shouval R, Elazar Z. ROS, mitochondria and the regulation of autophagy. Trends Cell Biol 2007; 17: 422-427.

14. Rubinsztein DC. The roles of intracellular protein-degradation pathways in neurodegeneration. Nature 2006; 443: 780-786.

15. Scherz-Shouval R, Shvets E, Fass E, Shorer H, Gil L, Elazar Z. Reactive oxygen species are essential for autophagy and specifically regulate the activity of Atg4. EMBO J2007; 26 $1749-1760$.

16. Xu Y, Kim SO, Li Y, Han J. Autophagy contributes to caspase-independent macrophage cell death. J Biol Chem 2006; 281: 19179-19187.

17. Chen Y, McMillan-Ward E, Kong J, Israels SJ, Gibson SB Oxidative stress induces autophagic cell death independent of apoptosis in transformed and cancer cells. Cell Death Differ 2008; 15: 171-182.

18. Wu YT, Tan HL, Huang Q, Kim YS, Pan N, Ong WY et al. Autophagy plays a protective role during ZVAD-induced necrotic cell death. Autophagy 2008; 4: 457-466. 
19. Fiers W, Beyaert R, Declercq W, Vandenabeele P. More than one way to die: apoptosis necrosis and reactive oxygen damage. Oncogene 1999; 18: 7719-7730.

20. Matsui Y, Takagi H, Qu X, Abdellatif M, Sakoda H, Asano T et al. Distinct roles of autophagy in the heart during ischemia and reperfusion: roles of AMP-activated protein kinase and Beclin 1 in mediating autophagy. Circ Res 2007; 100: 914-922.

21. Zong WX, Ditsworth D, Bauer DE, Wang ZQ, Thompson CB. Alkylating DNA damage stimulates a regulated form of necrotic cell death. Genes Dev 2004; 18: 1272-1282.

22. Shen HM, Lin Y, Choksi S, Tran J, Jin T, Chang $L$ et al. Essential roles of receptorinteracting protein and TRAF2 in oxidative stress-induced cell death. Mol Cell Biol 2004; 24: 5914-5922.

23. Qu X, Zou Z, Sun Q, Luby-Phelps K, Cheng P, Hogan RN et al. Autophagy genedependent clearance of apoptotic cells during embryonic development. Cell 2007; 128: 931-946.

24. Kimura S, Noda T, Yoshimori T. Dissection of the autophagosome maturation process by a novel reporter protein, tandem fluorescent-tagged LC3. Autophagy 2007; 3: 452-460.

25. Corradetti MN, Guan KL. Upstream of the mammalian target of rapamycin: do all roads pass through mTOR? Oncogene 2006; 25: 6347-6360.

26. Kahn BB, Alquier T, Carling D, Hardie DG. AMP-activated protein kinase: ancient energy gauge provides clues to modern understanding of metabolism. Cell Metab 2005; 1: 15-25.

27. Sarbassov DD, Ali SM, Sabatini DM. Growing roles for the mTOR pathway. Curr Opin Cell Biol 2005; 17: 596-603.

28. Zhou G, Myers R, Li Y, Chen Y, Shen X, Fenyk-Melody J et al. Role of AMP-activated protein kinase in mechanism of metformin action. J Clin Invest 2001; 108: 1167-1174.

29. Woods A, Johnstone SR, Dickerson K, Leiper FC, Fryer LG, Neumann D et al. LKB1 is the upstream kinase in the AMP-activated protein kinase cascade. CurrBiol 2003; 13: 2004-2008.

30. Hardie DG. AMP-activated/SNF1 protein kinases: conserved guardians of cellular energy. Nat Rev Mol Cell Biol 2007; 8: 774-785.

31. Castedo M, Ferri KF, Kroemer G. Mammalian target of rapamycin (mTOR): pro- and antiapoptotic. Cell Death Differ 2002; 9: 99-100.

32. Slupphaug G, Kavli B, Krokan HE. The interacting pathways for prevention and repair of oxidative DNA damage. Mutat Res 2003; 531: 231-251.

33. Yu SW, Andrabi SA, Wang H, Kim NS, Poirier GG, Dawson TM et al. Apoptosis-inducing factor mediates poly(ADP-ribose) (PAR) polymer-induced cell death. Proc Natl Acad Sc USA 2006; 103: 18314-18319.
34. Meley D, Bauvy C, Houben-Weerts $\mathrm{JH}$, Dubbelhuis PF, Helmond MT, Codogno P et al. AMP-activated protein kinase and the regulation of autophagic proteolysis. J Biol Chem 2006; 281: 34870-34879.

35. Sanders MJ, Grondin PO, Hegarty BD, Snowden MA, Carling D. Investigating the mechanism for AMP activation of the AMP-activated protein kinase cascade. Biochem $\mathrm{J}$ 2007; 403: 139-148.

36. Walker JW, Jijon HB, Madsen KL. AMP-activated protein kinase is a positive egulator of poly(ADP-ribose) polymerase. Biochem Biophys Res Commun 2006; 342: 336-341.

37. Gwinn DM, Shackelford DB, Egan DF, Mihaylova MM, Mery A, Vasquez DS et al. AMPK phosphorylation of raptor mediates a metabolic checkpoint. Mol Cell 2008; 30: 214-226.

38. Xu ZX, Liang J, Haridas V, Gaikwad A, Connolly FP, Mills GB et al. A plant triterpenoid, avicin $D$, induces autophagy by activation of AMP-activated protein kinase. Cell Death Differ 2007; 14: 1948-1957.

39. Huang X, Wullschleger S, Shpiro N, McGuire VA, Sakamoto K, Woods YL et al. Important role of the LKB1-AMPK pathway in suppressing tumorigenesis in PTEN-deficient mice. Biochem J 2008; 412: 211-221.

40. Hadad SM, Fleming S, Thompson AM. Targeting AMPK: a new therapeutic opportunity in breast cancer. Crit Rev Oncol Hematol 2008; 67: 1-7.

41. Karantza-Wadsworth V, Patel S, Kravchuk O, Chen G, Mathew R, Jin S et al. Autophagy mitigates metabolic stress and genome damage in mammary tumorigenesis. Genes Dev 2007; 21: 1621-1635.

42. Degenhardt K, Mathew R, Beaudoin B, Bray K, Anderson D, Chen G et al. Autophagy promotes tumor cell survival and restricts necrosis, inflammation, and tumorigenesis. Cancer Cell 2006; 10: 51-64.

43. Yu L, Alva A, Su H, Dutt P, Freundt E, Welsh $S$ et al. Regulation of an ATG7-beclin 1 program of autophagic cell death by caspase-8. Science 2004; 304 : 1500-1502.

44. Ditsworth D, Zong WX, Thompson CB. Activation of poly(ADP)-ribose polymerase (PARP1) induces release of the pro-inflammatory mediator HMGB1 from the nucleus. J Biol Chem 2007; 282: 17845-17854.

45. Amaravadi RK, Yu D, Lum JJ, Bui T, Christophorou MA, Evan Gl et al. Autophagy inhibition enhances therapy-induced apoptosis in a Myc-induced model of lymphoma. J Clin Invest 2007; 117: 326-336.

Supplementary Information accompanies the paper on Cell Death and Differentiation website (http://www.nature.com/cdd) 


\title{
Retraction
}

\section{Retraction: A novel function of poly(ADP-ribose) polymerase-1 in modulation of autophagy and necrosis under oxidative stress}

\author{
Q Huang, Y-T Wu, H-L Tan, C-N Ong and H-M Shen \\ Cell Death and Differentiation (2010) 17, 1944; doi:10.1038/cdd.2010.121; published online 24 September 2010
}

Retraction to: Cell Death and Differentiation (2009)16, 264-277; doi: 10.1038/cdd.2008.151; published online 31 October 2008

The authors would like to retract the above article.

Recently, the authors were alerted by the journal's editors to some discrepancies in their data. After a careful review, sufficient errors and mistakes were found that, although the authors still believe the conclusions of the paper to be valid, all the authors agreed to retract this article so as not to leave potentially misleading data in the literature.

The authors would like to offer their sincere apologies to the readers for these errors and mistakes. 